\section{(A) Check for updates}

Cite this: Dalton Trans., 2021, 50 2472

Received 18th December 2020 Accepted 19th January 2021

DOI: $10.1039 / \mathrm{d} 0 \mathrm{dt} 04303 f$

rsc.li/dalton

\title{
Synthesis and reactivity of iridium complexes of a macrocyclic PNP pincer ligand $\uparrow$
}

\begin{abstract}
Thomas M. Hood (D) and Adrian B. Chaplin (D) *
Having recently reported on the synthesis and rhodium complexes of the novel macrocyclic pincer ligand PNP-14, which is derived from lutidine and features terminal phosphine donors trans-substituted with a tetradecamethylene linker (Dalton Trans., 2020, 49, 2077-2086 and Dalton Trans., 2020, 49, 16649-16652), we herein describe our findings critically examining the chemistry of iridium homologues. The five-coordinate iridium(I) and iridium(III) complexes $\left[\operatorname{Ir}(\mathrm{PNP}-14)\left(\eta^{2}: \eta^{2}\right.\right.$-cyclooctadiene)][BAr$\left.{ }_{4}\right]$ and $[\mathrm{Ir}$ (PNP-14)(2,2'-biphenyl)][BAr $\left.{ }_{4}\right]$ are readily prepared and shown to be effective precursors for the generation of iridium(III) dihydride dihydrogen, iridium(।) bis(ethylene), and iridium(।) carbonyl derivatives that highlight important periodic trends by comparison to rhodium counterparts. Reaction of $[\operatorname{Ir}(\mathrm{PNP}-14)$ $\left.\mathrm{H}_{2}\left(\mathrm{H}_{2}\right)\right]\left[\mathrm{BAr}_{4}{ }_{4}\right]$ with 3,3-dimethylbutene induced triple $\mathrm{C}-\mathrm{H}$ bond activation of the methylene chain, yielding an iridium(III) allyl hydride derivative $\left[\operatorname{Ir}\left(\mathrm{PNP}-14^{*}\right) \mathrm{H}\right]\left[\mathrm{BAr}_{4}\right]$, whilst catalytic homocoupling of 3,3-dimethylbutyne into $Z-t \mathrm{BuC} \equiv \mathrm{CCHCH} t \mathrm{Bu}$ could be promoted at RT by $\left[\operatorname{Ir}(\mathrm{PNP}-14)\left(\eta^{2}: \eta^{2}-\right.\right.$ cyclooctadiene)] $\left[\mathrm{BAr}_{4}{ }_{4}\right]\left(\mathrm{TOF}_{\text {initial }}=28 \mathrm{~h}^{-1}\right)$. The mechanism of the latter is proposed to involve formation and direct reaction of a vinylidene derivative with $\mathrm{HC} \equiv \mathrm{CtBu}$ outside of the macrocyclic ring and this suggestion is supported experimentally by isolation and crystallographic characterisation of a catalyst deactivation product.
\end{abstract}

\section{Introduction}

Phosphine-based pincers are robust ancillary ligands that continue to find notable applications in organometallic chemistry and homogenous catalysis. ${ }^{1,2}$ In particular, rhodium and iridium complexes of these ligands are associated with fundamental and applied breakthroughs in the chemistry of $\mathrm{C}-\mathrm{H}$ bond activation reactions; exemplified by the characterisation of $\sigma$-alkane complexes and development of high-performance alkane dehydrogenation catalysts, respectively. ${ }^{3,4}$ These mer-tridentate ligands are evidently well-suited to supporting the formation of highly reactive $\mathrm{M}(\mathrm{I})$ derivatives necessary to bring about cleavage of strong $\mathrm{C}-\mathrm{H}$ bonds,${ }^{5}$ able to accommodate the changes in geometry associated with $\mathrm{M}(\mathrm{I}) / \mathrm{M}$ (III) redox shuttling, and suitably modular in composition to enable augmentation of metal-based reactivity through considered change of the central donor atom, wingtip substituents, or backbone

Department of Chemistry, University of Warwick, Gibbet Hill Road, Coventry CV4 7AL, UK. E-mail: a.b.chaplin@warwick.ac.uk

$\dagger$ Electronic supplementary information (ESI) available: Catalytic homocoupling of 3,3-dimethylbutyne promoted by $\mathbf{6}$, synthesis and characterisation of $\left[\mathrm{Rh}(\mathrm{PNP}-14)\left(\eta^{2}\right.\right.$-norbornene $\left.)\right]\left[\mathrm{BAr}_{4}^{\mathrm{F}}\right]$; NMR, IR and ESI-MS spectra of new compounds, and selected reactions (PDF). Primary NMR data (MNOVA). CCDC 2051203-2051207. For ESI and crystallographic data in CIF or other electronic format see DOI: 10.1039/d0dt04303f constituents. $^{2}$ As marked out by lower carbonyl stretching frequencies, ${ }^{6}$ the heavier iridium congeners are particularly notable for a more pronounced tendency for oxidative addition of $\mathrm{H}_{2},{ }^{7,8} \mathrm{C}\left(\mathrm{sp}^{3}\right)-\mathrm{H}$ bonds, ${ }^{3,9}$ and $\mathrm{C}\left(\mathrm{sp}^{2}\right)-\mathrm{H}$ bonds ${ }^{10}$ compared to their rhodium counterparts.

Motivated by the potential to exploit additional reaction control though their unique steric profile, use in the construction of interlocked assemblies, and as an extension of our related work with NHC-based variants, ${ }^{11-13}$ we have recently become interested in the chemistry of macrocyclic phosphinebased pincers. ${ }^{14-16}$ Last year we reported on the synthesis and rhodium complexes of the lutidine-derived macrocyclic pincer PNP-14, where the chiral P-donors are trans-substituted with a tetradecamethylene linker (Chart 1). ${ }^{14,15}$ As a novel platform for exploring the organometallic chemistry of Group 9 pincer complexes, we now present our findings critically examining

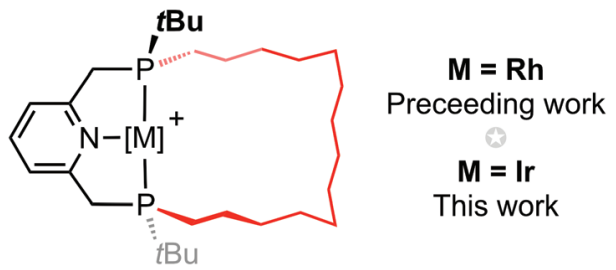

Chart 1 Complexes of the macrocyclic pincer ligand PNP-14. 
the chemistry of iridium PNP-14 homologues aided by reference to acyclic complexes of 2,6- $\left(\mathrm{R}_{2} \mathrm{PCH}_{2}\right)_{2} \mathrm{C}_{5} \mathrm{H}_{3} \mathrm{~N}$ (PNP-R; e.g. $\mathrm{R}=t \mathrm{Bu}, i \mathrm{Pr})$.

\section{Results and discussion}

Mirroring synthetic strategies that we have successfully employed for rhodium homologues, ${ }^{14,15}$ the preparation of iridium(I) and iridium(III) complexes of PNP-14 was attempted through substitution reactions of $\left[\operatorname{Ir}(\mathrm{COD})_{2}\right]\left[\mathrm{BAr}_{4}^{\mathrm{F}}\right]^{17}$ in 1,2difluorobenzene (DFB) and $[\operatorname{Ir}(\mathrm{COD})(\mathrm{biph}) \mathrm{Cl}]_{2}{ }^{18}$ in fluorobenzene, respectively, with the latter exploiting $\mathrm{Na}\left[\mathrm{BAr}_{4}{ }_{4}\right]$ as a halide abstracting agent (COD $=1,5$-cyclooctadiene, $\mathrm{Ar}^{\mathrm{F}}=3,5$ $\left(\mathrm{CF}_{3}\right)_{2} \mathrm{C}_{6} \mathrm{H}_{3}$, biph = 2,2'-biphenyl; Scheme 1). These reactions produced five-coordinate cationic derivatives $\left[\operatorname{Ir}(\mathrm{PNP}-14)\left(\eta^{2}: \eta^{2}\right.\right.$ $\mathrm{COD})]\left[\mathrm{BAr}_{4}^{\mathrm{F}}\right] \mathbf{1}$ and $[\operatorname{Ir}(\mathrm{PNP}-14)(\mathrm{biph})]\left[\mathrm{BAr}_{4}^{\mathrm{F}}\right] 2$ under mild conditions, which were subsequently isolated as analytically pure crystalline materials in good yield (ca. 80\%) and fully characterised (Scheme 1).

Iridium(I) complex $\mathbf{1}$ adopts a distorted trigonal bipyramidal metal geometry (18 VE), with the terminal phosphine donors positioned in the equatorial coordination sites conferring a distinctly puckered pincer ligand geometry. Distortion of the PNP ligand towards a fac coordination mode in this manner is associated with a compressed $\mathrm{P}-\mathrm{Ir}-\mathrm{P}$ bite angle of $115.24(2)^{\circ}$ in the solid state and a pair of ${ }^{31} \mathrm{P}$ resonances at $\delta$
17.0 and 13.4 with no appreciable ${ }^{2} J_{\mathrm{PP}}$ coupling in DFB solution. While unusual, the formulation of 1 simply appears to be a consequence of COD chelation, although this is contingent upon the flexible lutidine-based backbone and asymmetric steric profile of the phosphine donors. ${ }^{19}$ Moreover, given the rhodium(I) homologue is instead characterised as a $C_{1}$-symmetric square planar complex, viz. $\left[\mathrm{Rh}(\mathrm{PNP}-14)\left(\eta^{2}-\mathrm{COD}\right)\right]^{+}\left(\mathbf{1}^{\prime}\right.$, $\left.16 \mathrm{VE} ; \delta_{31} \mathrm{P} 57.4,45.9,{ }^{2} \mathrm{JP}_{\mathrm{PP}}=312 \mathrm{~Hz}\right),{ }^{15,20}$ the capacity of the heavier metal congener to from stronger metal-ligand bonds is clearly a decisive factor. Bulk purity was established by combustion analysis and the structure of $\mathbf{1}$ was fully corroborated in solution by NMR spectroscopy and HR ESI-MS.

Coordination of PNP-14 is more conventional in the formally 16 VE square pyramidal iridium(III) complex 2 , as evidenced by a P-Ir-P bite angle of $163.24(5)^{\circ}$ in the solid state and $C_{1}$ symmetry in $\mathrm{CD}_{2} \mathrm{Cl}_{2}$ solution; with a pair of ${ }^{31} \mathrm{P}$ resonances at $\delta 38.7$ and 20.9 exhibiting a characteristically large trans-phosphine ${ }^{2} J_{\mathrm{PP}}$ coupling constant of $307 \mathrm{~Hz}^{21}$ The crystal structure of 2 is isomorphous to the direct rhodium homologue $2{ }^{\prime}{ }^{14}$ with the tetradecamethylene linker skewed to one side of the basal plane away from the biph ligand and contorted in such a way as to enable adoption of a weak $\gamma$-agostic interaction $(2$, Ir1 $\cdots \mathrm{H}-\mathrm{C} 129=$ 3.152(7); cf. 3.184(2) ^ for $2^{\prime}$ ). Previously reported five-coordinate complexes of the form $\left[\mathrm{M}\right.$ (pincer)(biph)][BAr$\left.{ }_{4}^{\mathrm{F}}\right]$ provide further structural precedent for 2 and the metal-based metrics of the acyclic analogue $[\operatorname{Ir}(\mathrm{PNP}-t \mathrm{Bu})(\mathrm{biph})]\left[\mathrm{BAr}_{4}^{\mathrm{F}}\right]$ (II) are similar. ${ }^{6,11,14}$ Moreover, as II is fluxional in solution as a result

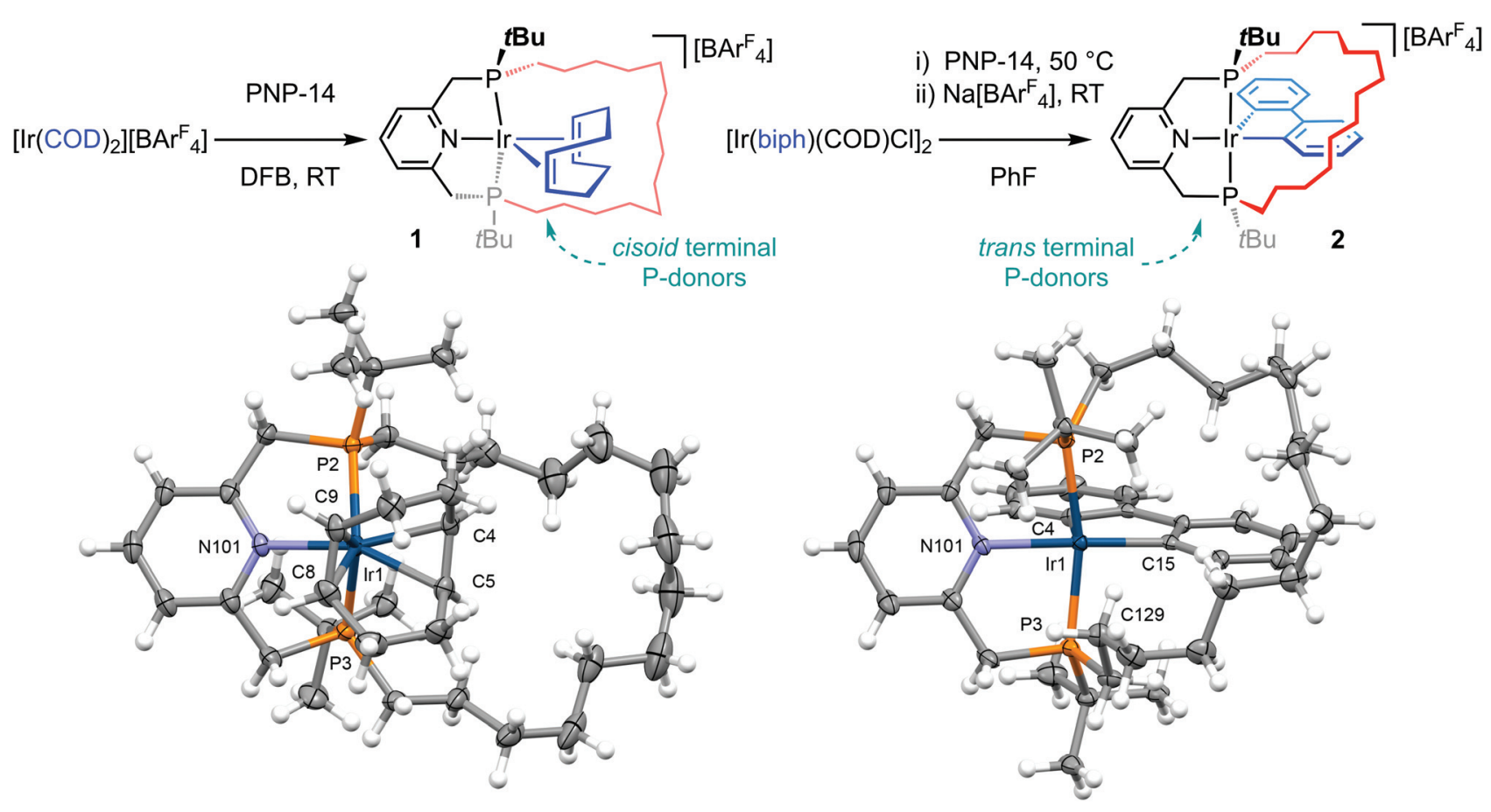

Scheme 1 Synthesis and solid-state structures of iridium pincer complexes 1 and 2: thermal ellipsoids at 50\% and 30\% probability, respectively; anions omitted. Selected bond lengths (Å) and angles ( $\left.{ }^{\circ}\right)$ : 1, Ir1-P2, 2.3743(7); Ir1-P3, 2.3846(7); P2-Ir1-P3, 115.24(2); Ir1-N101, 2.107(2); Ir1-Cnt (C4,C5), 2.083(2); Ir1-Cnt(C8, C9), 2.036(2); N101-Ir1-Cnt(C4, C5), 172.52(8); Cnt(C4, C5)-Ir-Cnt(C8, C9), 84.29(9); 2, Ir1-P2, 2.3253(15); Ir1-P3,

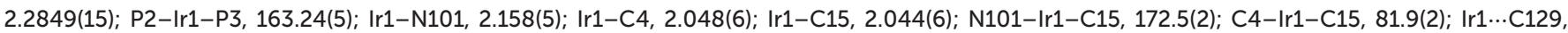
3.152(7); Ir1…HC129, 2.54; Cnt = centroid. 
of facile biph pseudorotation on the NMR timescale, ${ }^{6}$ retention of $C_{1}$ symmetry in solution suggests that buttressing with the methylene strap prevents such dynamics in 2 .

Reaction of 2 with dihydrogen ( $1 \mathrm{~atm})$ in DFB at RT resulted in immediate and full conversion into [ $\operatorname{Ir}(\mathrm{PNP}-14)(2$-biphenyl) $\mathrm{H}]\left[\mathrm{BAr}_{4}^{\mathrm{F}}\right] 3\left(\delta_{31} \mathrm{P} 40.6,36.5,{ }^{2} J_{\mathrm{PP}}=302 \mathrm{~Hz} ; \delta_{1_{\mathrm{H}}}-21.6\right.$; Scheme 2$)$. No further reaction was observed after $18 \mathrm{~h}$, but heating at $85^{\circ} \mathrm{C}$ for $6 \mathrm{~h}$ resulted in complete hydrogenolysis of the biph ligand and formation of dihydride dihydrogen complex [Ir (PNP-14) $\left.\mathrm{H}_{2}\left(\mathrm{H}_{2}\right)\right]\left[\mathrm{BAr}_{4}^{\mathrm{F}}\right] \mathbf{4}$ in quantitative spectroscopic yield. Hydrogenolysis also occurs for $2^{\prime}$ and II, but longer reaction times are required under otherwise equivalent conditions (both ca. 2 days). ${ }^{14}$ Coordinatively saturated 1 rapidly affords 4 upon reaction with dihydrogen ( $1 \mathrm{~atm})$ in DFB at RT ( $<5 \mathrm{~min})$, invoking facile and reversible chelation of COD.

Complex 4 was characterised in situ using NMR spectroscopy, with adoption of time-averaged $C_{2}$ symmetry, a single ${ }^{31} \mathrm{P}$ resonance at $\delta 42.1$, and a broad $4 \mathrm{H}$ resonance at $\delta-9.26\left(T_{1}=\right.$ $88.8 \pm 0.7 \mathrm{~ms}, 600 \mathrm{MHz}$, argon) the most diagnostic features at $298 \mathrm{~K}$. The hydride signal remained broad upon cooling to $253 \mathrm{~K}$ but exhibits faster spin-lattice relaxation $(\delta-9.27$, $T_{1}=50 \pm 1 \mathrm{~ms}, 600 \mathrm{MHz}$, argon). The acyclic analogue $\left[\operatorname{Ir}(\mathrm{PNP}-t \mathrm{Bu}) \mathrm{H}_{2}\left(\mathrm{H}_{2}\right)\right] \mathrm{BF}_{4}$ (IV) is known and formulation as a dihydride dihydrogen complex was corroborated in a similar manner in situ by NMR spectroscopy. ${ }^{7}$ Whilst the data was recorded under difference conditions, the similarly of the hydride signatures is striking (IV, $\delta_{{ } \mathrm{H}}-9.31, T_{1}=24 \mathrm{~ms}, 400 \mathrm{MHz}, 233 \mathrm{~K}$ in $\mathrm{CD}_{3} \mathrm{OD}$ ). In line with the reduced propensity for oxidative addition, the rhodium homologue of $\mathbf{4}$ is instead observed as a dihydrogen complex, viz. $\left[\mathrm{Rh}(\mathrm{PNP}-14)\left(\mathrm{H}_{2}\right)\right]\left[\mathrm{BAr}_{4}^{\mathrm{F}}\right] \mathbf{4}^{\prime} .^{14}$

Further supporting the assignment of $\mathbf{4}$, reaction with ethylene ( $1 \mathrm{~atm})$ generated the corresponding $C_{1}$-symmetric dihydride $\pi$-complex $5\left(\delta_{31}\right.$ 33.4, 12.4, $\left.{ }^{2} J_{\mathrm{PP}}=314 ; \delta_{1_{\mathrm{H}}}-7.89,-17.80\right)$ within $5 \mathrm{~min}$ at RT (Scheme 2). Subsequent heating at $85{ }^{\circ} \mathrm{C}$ for $16 \mathrm{~h}$ yielded the bis(ethylene) complex $6\left(\delta_{31 \mathrm{P}} 9.0\right)$ in quantitative spectroscopic yield, with concomitant formation of ethane. $C_{2}$ symmetry and coordination of two molecules of ethylene was established in situ by NMR spectroscopy. The latter is associated with four chemically inequivalent $2 \mathrm{H}$ signals at $\delta 3.23,2.80,2.49$ and 1.97 and two ${ }^{13} \mathrm{C}$ resonances at $\delta 26.0$ and 18.0, and reinforces the disposition of iridium(I) centres to adopt five-coordinate geometries: as seen in 2 , but contrasting that observed under the same conditions in the rhodium(I) system, viz. $\left[\mathrm{Rh}(\mathrm{PNP}-14)\left(\mathrm{C}_{2} \mathrm{H}_{4}\right)\right]\left[\mathrm{BAr}^{\mathrm{F}}{ }_{4}\right] \quad \mathbf{6}^{\prime} .^{14}$ Structurally-related bis(ethylene) iridium(I) complexes of CNCand pybox-based pincer ligands have been crystallographically characterised, exhibiting distorted trigonal bipyramidal metal geometries with the ethylene ligands located in the equatorial sites, ${ }^{22}$ but are unknown for PNP- and PONOP-based ligands. ${ }^{23}$

When 2 was instead treated with an excess of 3,3-dimethylbutene ( 5 equivalents) the allyl hydride derivative $\left[\operatorname{Ir}\left(\mathrm{PNP}-14^{*}\right)\right.$ $\mathrm{H}]\left[\mathrm{BAr}_{4}^{\mathrm{F}}\right] 7$ was produced in quantitative spectroscopic yield after 5 days heating at $100{ }^{\circ} \mathrm{C}$, presumably through intramolecular transfer dehydrogenation of the methylene chain followed by allylic $\mathrm{C}-\mathrm{H}$ activation (Scheme 2). ${ }^{24}$ As precedent for this reactivity, examples of cyclometallated rhodium(III) and iridium(III) pincer complexes can be found in the literature. ${ }^{25}$ Complex 7 was subsequentially isolated in $49 \%$ yield and fully characterised, including in the solid state by single crystal X-ray diffraction (Fig. 1). In solution 7 is distinctly $C_{1}$ symmetric, with a pair of ${ }^{31} \mathrm{P}$ resonances at $\delta 81.4$ and 25.8 with ${ }^{2} J_{\mathrm{PP}}=313 \mathrm{~Hz}$, allyl ${ }^{13} \mathrm{C}$ resonances at $\delta 81.9,66.0$, and 38.9 , and a $1 \mathrm{H}$ hydride resonance at $\delta-8.49\left({ }^{2} J_{\mathrm{PH}}=19.6,9.7\right.$ $\mathrm{Hz}$ ). The crystal structure demonstrates that 7 adopts a pseudo-octahedral metal geometry in the solid state, with $\kappa_{6}$ coordination of PNP-14* creating iridacyclopentyl and iridacyclododecyl rings, and the hydride ligand was located from the Fourier difference map. Little distortion of the PNP-core is evident in 7 and the associated metal-based metrics are broadly comparable to those in 2 (e.g. P-Ir-P ca. 163 ). There is considerable variance in the allyl $\mathrm{Ir}-\mathrm{C}$ bond lengths, with the longest contact trans to the hydride ligand (Ir1-C119 =

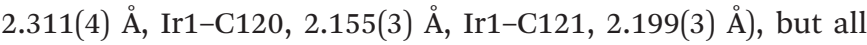
the internal carbon bond angles are $>120^{\circ}$. The geometry of

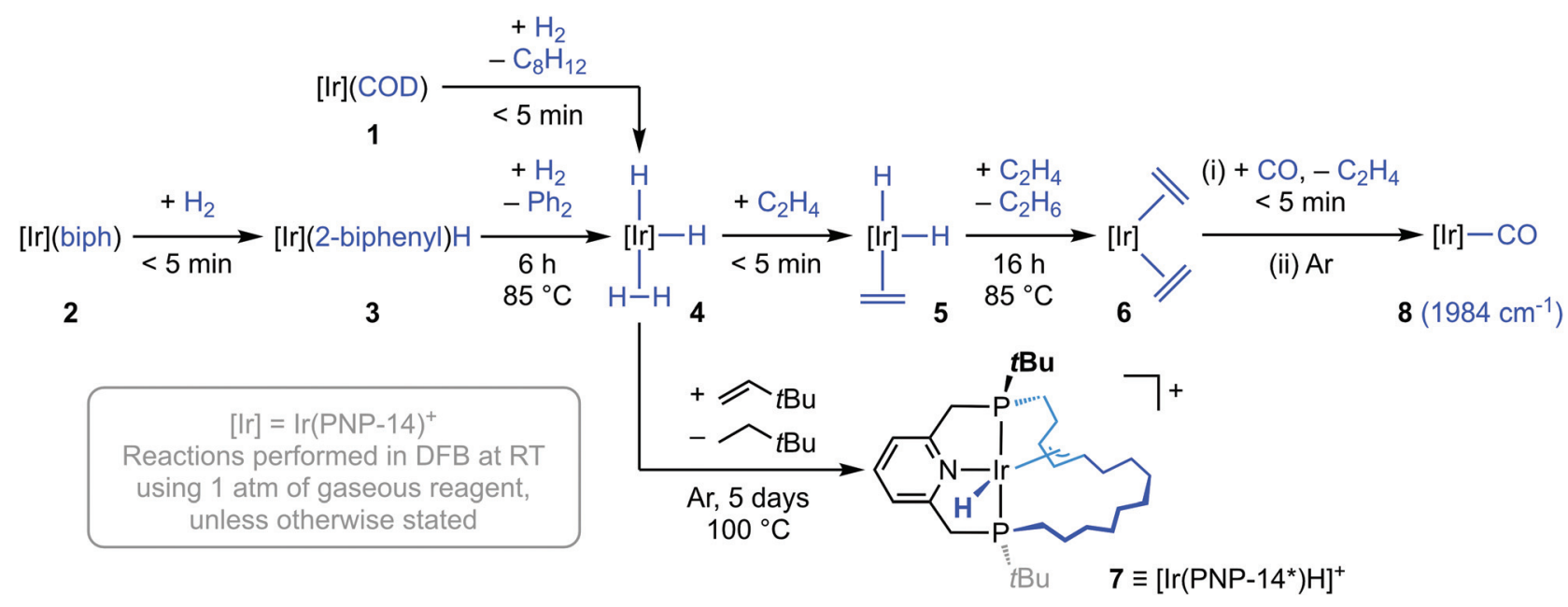

Scheme 2 Synthesis and reactivity of iridium dihydride dihydrogen complex 4. [BAr $\left.{ }_{4}\right]^{-}$counter anions omitted for clarity. 


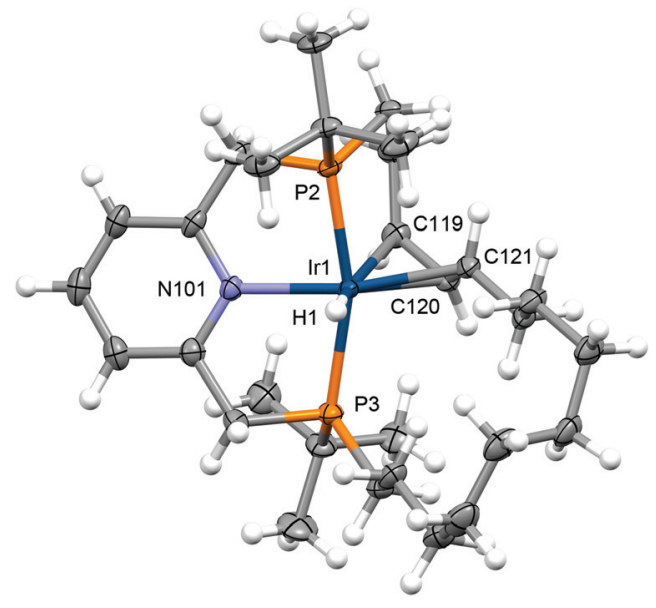

Fig. 1 Solid-state structure of 7: the hydride ligand was located from the Fourier difference map; thermal ellipsoids at 30\% probability; solvent molecule and anion omitted. Selected bond lengths $(\AA)$ and angles $\left({ }^{\circ}\right)$ : Ir1-P2, 2.2694(8); Ir1-P3, 2.3339(9); P2-Ir1-P3, 163.04(3); Ir1-N101, 2.126(2); Ir1-H1, 1.39(3); Ir1-C119, 2.311(4); Ir1-C120, 2.155(3); Ir1-C121, 2.199(3); C119-C120, 1.430(5); C120-C121, 1.409(5); C119-C120-C121, 124.4(3); N101-Ir1-C121, 169.59(11).

the iridacyclododecyl ring is reminiscent of the quadrilateral conformations adopted by 12 -membered cycloalkanes. ${ }^{26}$

The onward reactivity of $\mathbf{6}$ was harnessed to access the $C_{2}$ symmetric $\operatorname{Ir}(\mathrm{I})$ carbonyl derivative $8\left(\delta_{31 \mathrm{P}} 62.5\right)$ by reaction with carbon monoxide, which was isolated in $89 \%$ yield (overall from 2; Scheme 2). Complexes of this nature are of interest as the carbonyl ligand is a convenient spectroscopic reporter group for the electronic characteristics of the metal-pincer fragment. ${ }^{27,28}$ In this case, the $\nu(\mathrm{CO})$ band of $8\left(1984 \mathrm{~cm}^{-1}\right)$ is shifted to considerably lower frequency compared to the rhodium(I) homologue $\mathbf{8}^{\prime}\left(1997 \mathrm{~cm}^{-1}\right.$ ) under the same conditions $\left(\mathrm{CH}_{2} \mathrm{Cl}_{2}\right.$ solution, Table 1$)$. This is in line with expected periodic trends, which are also apparent from the IR data collected for $t \mathrm{Bu}-$ and $i$ Pr-substituted analogues. These data suggest that PNP-14 is a marginally weaker net donor than PNP- $t \mathrm{Bu}$, but equivalent to PNP-iPr. ${ }^{14}$

Of the organometallic chemistry we have discovered so far using PNP-14, the capacity for rhodium complexes to promote the stoichiometric homocoupling of 3,3-dimethylbutyne through the annulus of the macrocyclic ligand stands out $\left(\mathbf{1}^{\prime}\right.$ $\rightarrow \mathbf{9}^{\prime}$ in Scheme 3). ${ }^{15}$ Given that a structurally related $\operatorname{Ir}(\mathrm{PCP})$ system has also been shown to promote stoichiometric term-

Table 1 Carbonyl stretching frequencies $\left(\mathrm{CH}_{2} \mathrm{Cl}_{2}\right)$

\begin{tabular}{lll}
\hline Pincer & $\nu(\mathrm{CO}) / \mathrm{cm}^{-1}$ & Ref. \\
\hline$[\operatorname{Ir}(\mathrm{PNP}-14)(\mathrm{CO})]\left[\mathrm{BAr}^{\mathrm{F}}{ }_{4}\right] \mathbf{8}$ & 1984 & This work \\
{$[\mathrm{Rh}(\mathrm{PNP}-14)(\mathrm{CO})]\left[\mathrm{BAr}^{\mathrm{F}}{ }_{4}\right] \mathbf{8}^{\prime}$} & 1997 & 14 \\
{$[\mathrm{Ir}(\mathrm{PNP}-t \mathrm{Bu})(\mathrm{CO})]\left[\mathrm{BAr}^{\mathrm{F}}{ }_{4}\right]$} & 1977 & 6 \\
{$[\mathrm{Rh}(\mathrm{PNP}-t \mathrm{Bu})(\mathrm{CO})]\left[\mathrm{BAr}^{\mathrm{F}}{ }_{4}\right]$} & 1990 & 6 \\
{$[\operatorname{Ir}(\mathrm{PNP}-i \mathrm{Pr})(\mathrm{CO})]\left[\mathrm{BAr}^{\mathrm{F}}{ }_{4}\right]$} & $1986^{a}$ & 29 \\
{$[\mathrm{Rh}(\mathrm{PNP}-i \mathrm{Pr})(\mathrm{CO})]\left[\mathrm{BAr}^{\mathrm{F}}{ }_{4}\right]$} & 1998 & 27
\end{tabular}

${ }^{a}$ Measured in the solid state (ATR).

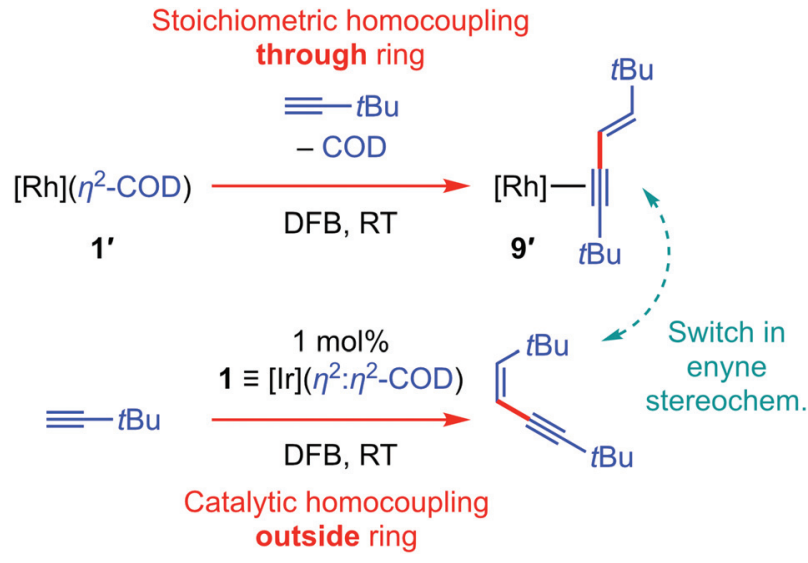

Scheme 3 Terminal alkyne coupling reactions promoted by 1 and $1^{\prime}$ : $[\mathrm{M}]=\mathrm{M}(\mathrm{PNP}-14)^{+}$.

inal alkyne coupling reactions, ${ }^{30,31}$ we were very interested to ascertain if similar reactivity could be brought about in iridium complexes of PNP-14. Iridium(I) complex 1 was selected as the most suitable precursor and initial screening studies using a twofold excess of $\mathrm{HC} \equiv \mathrm{C} t \mathrm{Bu}$ in $\mathrm{DFB}$ at RT indicated rapid production of the corresponding $Z$-enyne $\left(\delta_{1_{\mathrm{H}}} 5.53\right.$, $\left.5.25 ;{ }^{3} J_{\mathrm{HH}}=11.9 \mathrm{~Hz}\right)^{32}$ without any observable consumption of 1 (Scheme 3). This stereochemistry contrasts that observed for the rhodium system and, as homocoupling through the macrocycle would be expected to result in an interpenetrated enyne complex, it appears that production of the enyne occurs catalytically outside the ring. Subsequent detailed investigation of this reaction using 100 equivalents $\mathrm{HC} \equiv \mathrm{C} t \mathrm{Bu}$ confirmed that 1 is an effective precatalyst. ${ }^{33}$ Under these conditions, the dimerisation of $\mathrm{HC} \equiv \mathrm{C} t \mathrm{Bu}$ into $Z$ - $t \mathrm{BuC} \equiv \mathrm{CCHCH} t \mathrm{Bu}$ proceeds with an initial TOF of $28 \mathrm{~h}^{-1}$. After $6 \mathrm{~h}$, analysis by ${ }^{1} \mathrm{H}$ NMR spectroscopy indicated complete consumption of $\mathrm{HC} \equiv \mathrm{C} t \mathrm{Bu}$ and exclusive production of $Z$ - $t \mathrm{BuC} \equiv \mathrm{CCHCH} t \mathrm{Bu}$. From the ${ }^{31} \mathrm{P}\left\{{ }^{1} \mathrm{H}\right\}$ NMR spectrum generation of a new organometallic species was apparent $\left(\mathbf{1 0}, \delta 25.0,16.3 ;{ }^{2} J_{\mathrm{PP}}=364 \mathrm{~Hz}\right)$, accounting for $88 \%$ of the metal-containing species with 1 making up $10 \%$. Addition of a further 50 equivalents of $\mathrm{HC} \equiv \mathrm{C} t \mathrm{Bu}$ induced complete conversion of $\mathbf{1}$ into $\mathbf{1 0}$ within $24 \mathrm{~h}$ but coincided with a halt in homocoupling, which plateaued at 65 TONs.

Repeating the homocoupling reaction on a larger scale under similar conditions enabled isolation of $\mathbf{1 0}$ from solution in $76 \%$ yield, which was subsequently identified as iridium(III) bis(alkenyl) complex $\left[\operatorname{Ir}(\mathrm{PNP}-14)\left(\eta^{3}-E-\mathrm{C}(\mathrm{C} \equiv \mathrm{C} t \mathrm{Bu}) \mathrm{CH} t \mathrm{Bu}\right)\left(\eta^{1}-E-\right.\right.$ $\mathrm{CHCH} t \mathrm{Bu})]\left[\mathrm{BAr}^{\mathrm{F}}{ }_{4}\right]$ (Scheme 4$)$. In the solid state, 10 adopts a very distorted octahedral geometry with the alkenyl ligands in a cis configuration $\left(\mathrm{C} 4-\mathrm{Ir} 1-\mathrm{C} 6=102.50(9)^{\circ}\right)$ and coordination of the $\sigma$-organyl derived from $Z$ - $t \mathrm{BuC} \equiv \mathrm{CCHCH} t \mathrm{Bu}$ reinforced by $\pi$-complexation of the alkyne (Ir1-alkyne $=2.505(2) \AA)$ : a binding mode, for which there are no crystallographically characterised Group 9 precedents to our knowledge (CSD 5.41) ${ }^{34}$ The respective alkenyl $\mathrm{Ir}-\mathrm{C}$ and $\mathrm{C}=\mathrm{C}$ bond lengths are not statistically different $(\operatorname{Ir} 1-\mathrm{C} 4=2.043(2) \AA$, Ir1-C6 $=2.053(2)$ $\AA$; $\mathrm{C} 4-\mathrm{C} 5=1.330(3) \AA, \mathrm{C} 6-\mathrm{C} 9=1.329(3) \AA)$. The structure of $\mathbf{1 0}$ 

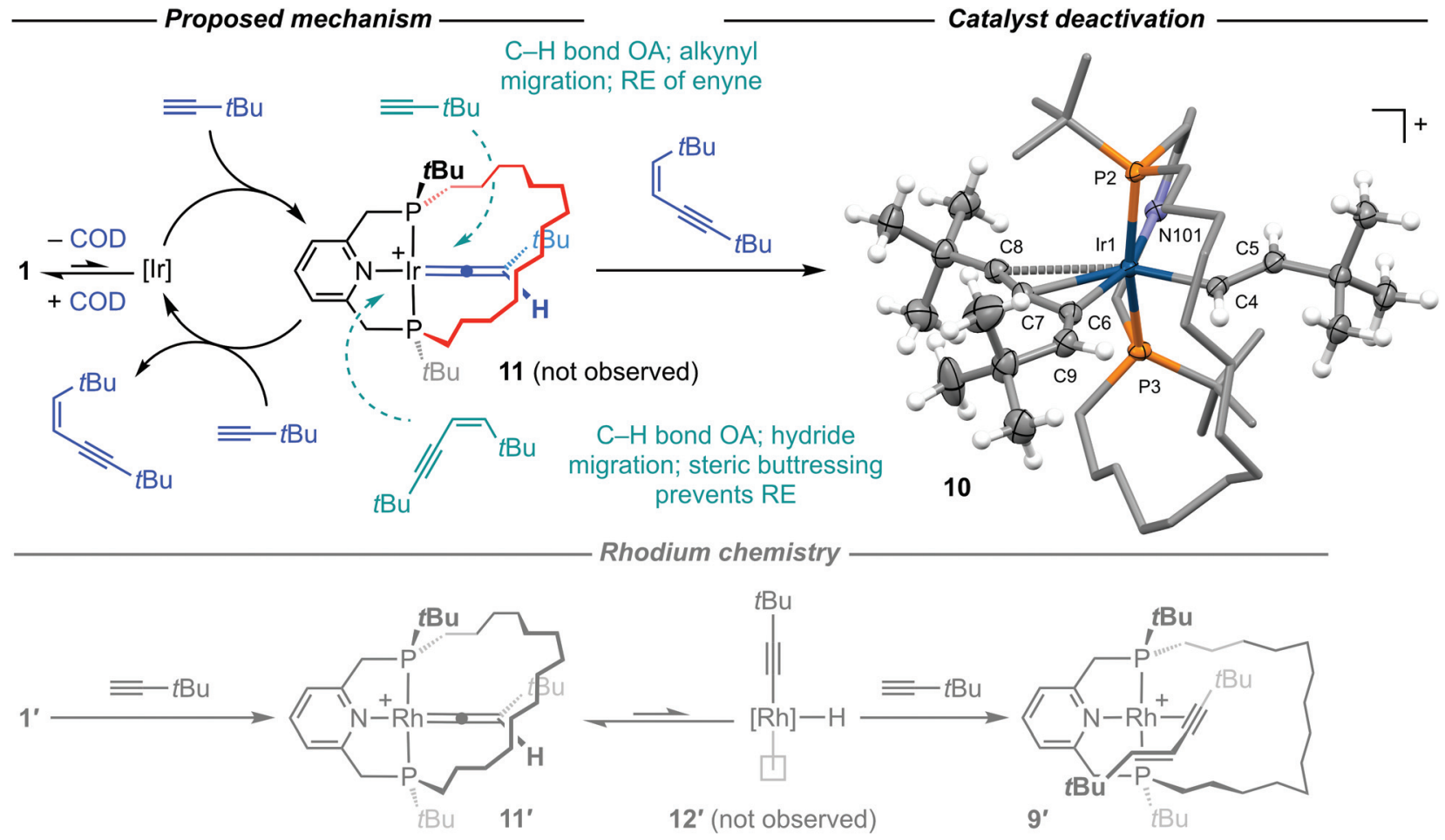

Scheme 4 Mechanistic features of the terminal alkyne coupling reactions promoted by 1 and $1^{\prime}:[M]=M(P N P-14)^{+}$and $\left[B A r^{F}\right]^{-}$counter anions omitted. Solid-state structure of 10 depicted with thermal ellipsoids at 30\% probability for selected atoms; minor disordered component (IrP ${ }_{2}$ core), most $\mathrm{H}$ atoms, and anion omitted; structural diagram provided in the experimental section. Selected bond lengths $(\AA)$ and angles $\left({ }^{\circ}\right)$ : Ir1-P2, 2.3141 (5); Ir1-P3, 2.3659(5); P2-Ir1-P3, 163.55(2); Ir1-N101, 2.122(2); Ir-C4, 2.043(2); Ir-C4-C5, 129.59(15); C4-C5, 1.330(3); Ir1-C6, 2.053(2); Ir1-C6C9, 147.4(2); C6-C9, 1.329(3); Ir1-Cnt(C7, C8), 2.505(2); C6-C7-C8, 161.9(2); C7-C8, 1.216(3); N101-Ir1-C6, 159.35(8); C4-Ir1-Cnt(C7, C8), 153.16 (7); C4-Ir1-C6, 102.50(9); Cnt = centroid.

determined by X-ray crystallography was fully corroborated in solution using NMR spectroscopy. For instance, the alkenyl ${ }^{1} \mathrm{H}$ resonances are located at $\delta 7.81\left(\operatorname{IrCHCH} t \mathrm{Bu} ;{ }^{3} J_{\mathrm{HH}}=15.0 \mathrm{~Hz}\right)$, $5.68(\operatorname{IrCCH} t \mathrm{Bu})$, and $4.78\left(\operatorname{IrCHCH} t \mathrm{Bu} ;{ }^{3} J_{\mathrm{HH}}=15.2 \mathrm{~Hz}\right)$ in a $1: 1: 1$ ratio, with the associated ${ }^{\overline{13}} \mathrm{C}$ resonances at $\delta 143.5$ (IrCHCHtBu), $142.2(\operatorname{IrCCH} t \mathrm{Bu}), 105.3(\operatorname{IrCCH} t \mathrm{Bu})$, and 95.7 (Ir $\underline{\mathrm{CHC}} \mathrm{H} t \mathrm{Bu})$; the $\alpha$-carbons exhibiting coupling to ${ }^{31} \mathrm{P}\left({ }^{2} J_{\mathrm{PC}}=\right.$ 5-10 Hz). The HR-ESI MS of $\mathbf{1 0}$ is also notable for a strong $[M]^{+}$ ion signal at 916.5623 (calcd 916.5628) $\mathrm{m} / \mathrm{z}$ and bulk purity of was confirmed by combustion analysis.

Terminal alkyne homocoupling reactions that produce $Z$-enyne products are generally understood to proceed via vinylidene intermediates, with $\mathbf{1 1}$ implicated in this case (Scheme 4) ${ }^{35,36}$ Indeed, the rhodium homologue $\mathbf{1 1}^{\prime}$ is produced initially upon reaction of $\mathbf{1}^{\prime}$ with $\mathrm{HC} \equiv \mathrm{C} t \mathrm{Bu} .{ }^{15}$ Reaction with the second alkyne equivalent, by net 1,2-addition of the constituent $\mathrm{C}(\mathrm{sp})-\mathrm{H}$ bond across the vinylidene $\mathrm{M}=\mathrm{C}$ linkage (concerted or step-wise) followed by reductive elimination, would thereafter confer the enyne product. $E$-Enyne isomers such as that observed in the rhodium system can also be produced in this manner, although an indirect route involving equilibrium generation of the rhodium(III) alkynyl hydride 12' is instead invoked in the formation of $\mathbf{9}^{\prime}$ from $\mathbf{1 1}^{\prime}$ (Scheme 4). Whilst 11 was not detected during the formation of $Z$ $t \mathrm{BuC} \equiv \mathrm{CCHCH} t \mathrm{Bu}$, the generation of $\mathbf{1 0}$ provides strong circumstantial evidence for its intermediate presence. No reac- tion between 1 and independently synthesised $Z$ $t \mathrm{BuC} \equiv \mathrm{CCHCH} t \mathrm{Bu}$ in DFB was observed, even upon heating at $50{ }^{\circ} \mathrm{C}$ for $1 \mathrm{~h}$. The formation of the bis(alkenyl) is, therefore, most reasonably reconciled by irreversible reaction of $Z$ $t \mathrm{BuC} \equiv \mathrm{CCHCH} t \mathrm{Bu}$ with 11; involving net 1,2-addition of the $\{\mathrm{C} \equiv \mathrm{C}\} \mathrm{C}\left(\mathrm{sp}^{2}\right)-\mathrm{H}$ bond across the $\mathrm{Ir}=\mathrm{C}$ linkage. The addition evidently takes place through the ring in this instance, with the macrocycle preventing subsequent reductive elimination. ${ }^{12}$ We therefore attribute the generation of $\mathbf{1 0}$ to catalyst deactivation by irreversible product inhibition. The postulated reactivity of the Group 9 vinylidenes derived from $\mathbf{1}$ and $\mathbf{1}^{\prime}$ is clearly nuanced by the nature of the metal and impact of the unique steric constraints imposed by the tetradecamethylene linker. We believe that the more facile $\operatorname{Ir}(\mathrm{I}) / \operatorname{Ir}(\mathrm{III})$ redox couple and propensity of the $\{\operatorname{Ir}(\mathrm{PNP}-14)\}^{+}$fragment to adopt geometries with the pincer ligand in a non-meridional conformation are the decisive factors. Specifically, we propose that the $Z$-selective homocoupling of $\mathrm{HC} \equiv \mathrm{C} t \mathrm{Bu}$ proceeds catalytically outside the ring via $\mathrm{C}(\mathrm{sp})-\mathrm{H}$ bond oxidative addition of $\mathrm{HC} \equiv \mathrm{C} t \mathrm{Bu}$ to 11 affording $f a c-[\operatorname{Ir}(\mathrm{PNP}-14)(\mathrm{CCH} t \mathrm{Bu})(\mathrm{C} \equiv \mathrm{C} t \mathrm{Bu}) \mathrm{H}]^{+}$, alkynyl migration yielding an enynyl hydride, and finally release of $Z$ - $t \mathrm{BuC} \equiv \mathrm{CCHCH} t \mathrm{Bu}$ by reductive elimination. In contrast, $\mathbf{1}^{\prime}$ mediates the stoichiometric $E$-selective homocoupling of $\mathrm{HC} \equiv \mathrm{C} t \mathrm{Bu}$ through the ring ultimately via a pathway bypassing the vinylidene intermediate $\mathbf{1 1}^{\prime}$. Further computational analysis would be required to corroborate these sug- 
gestions, although accurately modelling the effect of the methylene chain is non-trivial.

\section{Conclusions}

The organometallic chemistry of iridium complexes of the macrocyclic PNP-14 pincer ligand has been explored. The fivecoordinate iridium(I) and iridium(III) complexes [Ir(PNP-14) $\left.\left(\eta^{2}: \eta^{2}-\mathrm{COD}\right)\right]\left[\mathrm{BAr}^{\mathrm{F}}\right] \mathbf{1}$ and [Ir(PNP-14)(biph)][BAr $\left.{ }_{4}^{\mathrm{F}}\right] \mathbf{2}$ are readily prepared and fully characterised derivatives, with the former notable for a distorted trigonal bipyramidal metal geometry in which the pincer ligand adopts an unusual non-meridional confirmation, and the latter for adoption of a square pyramidal metal geometry stabilised by a weak $\gamma$-agostic interaction between the metal and the tetradecamethylene linker. These well-defined complexes have been shown to be effective precursors for the generation of iridium(III) dihydride dihydrogen (4), iridium(I) bis(ethylene) (6), and iridium(I) carbonyl (8) derivatives that highlight important periodic trends by comparison to rhodium counterparts: i.e. the more facile oxidative addition of dihydrogen, propensity to from five-coordinate $\mathrm{d}^{8}$ complexes, and greater $\pi$-basicity of the heavier metal conger, respectively.

Onward reactivity of the $\{\operatorname{Ir}(\mathrm{PNP}-14)\}^{+}$fragment was also explored with the bulky unsaturated substrates 3,3-dimethylbutene and 3,3-dimethylbutyne. Reaction of 4 with 3,3-dimethylbutene induced triple $\mathrm{C}-\mathrm{H}$ bond activation of the methylene chain yielding an iridium(III) allyl hydride complex [Ir(PNP-14*) $\mathrm{H}]\left[\mathrm{BAr}_{4}^{\mathrm{F}}\right] \mathbf{7}$, whilst $\mathbf{1}$ is an effective pre-catalyst for the homocoupling of 3,3-dimethylbutyne into $Z$ - $t \mathrm{BuC} \equiv \mathrm{CCHCH} t \mathrm{Bu}$ under mild conditions. The latter is particularly remarkable given that reaction of the homologous rhodium precursor $\mathbf{1}^{\prime}$ results in the formation of an interpenetrated $E$-enyne complex $\left(\mathbf{9}^{\prime}\right)$. The mechanism of the homocoupling promoted by $\mathbf{1}$ is proposed to involve formation and direct reaction of the (unobserved) vinylidene derivative $[\operatorname{Ir}(\mathrm{PNP}-14)(\mathrm{CCH} t \mathrm{Bu})]\left[\mathrm{BAr}_{4}^{\mathrm{F}}\right]$ (11) with $\mathrm{HC} \equiv \mathrm{C} t \mathrm{Bu}$ outside of the macrocyclic ring. This suggestion is supported experimentally by isolation and crystallographic characterisation of $\quad\left[\operatorname{Ir}(\mathrm{PNP}-14)\left(\eta^{3}-E-\mathrm{C}(\mathrm{C} \equiv \mathrm{C} t \mathrm{Bu}) \mathrm{CH} t \mathrm{Bu}\right)\left(\eta^{1}-E-\mathrm{CHCH} t \mathrm{Bu}\right)\right]\left[\mathrm{BAr}^{\mathrm{F}}{ }_{4}\right]$ (10), which results from deactivation of the catalyst by product inhibition.

\section{Experimental}

\subsection{General methods}

All manipulations were performed under an atmosphere of argon using Schlenk and glove box techniques unless otherwise stated. Dihydrogen and ethylene were dried by passage through a column of activated $3 \AA$ molecular sieves. Glassware was oven dried at $150{ }^{\circ} \mathrm{C}$ overnight and flame-dried under vacuum prior to use. Molecular sieves were activated by heating at $300{ }^{\circ} \mathrm{C}$ in vacuo overnight. Fluorobenzene and DFB were pre-dried over $\mathrm{Al}_{2} \mathrm{O}_{3}$, distilled from calcium hydride and dried twice over $3 \AA$ molecular sieves. ${ }^{37} \mathrm{CD}_{2} \mathrm{Cl}_{2}$ was freeze- pump-thaw degassed and dried over $3 \AA$ molecular sieves. $\mathrm{C}_{6} \mathrm{D}_{6}$ was distilled from sodium and stored over $3 \AA$ molecular sieves. $\mathrm{SiMe}_{4}$ was distilled from liquid $\mathrm{Na} / \mathrm{K}$ alloy and stored over a potassium mirror. Other anhydrous solvents and liquid reagents were purchased from Acros Organics or SigmaAldrich, freeze-pump-thaw degassed and stored over 3 A molecular sieves. PNP-14, ${ }^{14}\left[\operatorname{Ir}(\mathrm{COD})_{2}\right]\left[\mathrm{BAr}_{4}^{\mathrm{F}}\right],{ }^{17}[\operatorname{Ir}(\mathrm{biph})(\mathrm{COD})$ $\mathrm{Cl}]_{2},{ }^{18} \mathrm{Na}\left[\mathrm{BAr}_{4}^{\mathrm{F}}\right],{ }^{38}$ and $[\operatorname{Ir}(\mathrm{PNP}-t \mathrm{Bu})(\mathrm{biph})]\left[\mathrm{BAr}^{\mathrm{F}}{ }_{4}\right](\mathbf{I I})^{6}$ were synthesized according to published procedures. All other solid reagents are commercial products and were used as received. NMR spectra were recorded on Bruker spectrometers under argon at $298 \mathrm{~K}$ unless otherwise stated. Chemical shifts are quoted in ppm and coupling constants in Hz. Virtual coupling constants are reported as the separation between the first and third lines. NMR spectra in DFB were recorded using an internal capillary of $\mathrm{C}_{6} \mathrm{D}_{6}$ or acetone- $d_{6}{ }^{37}$ High resolution ESI-MS were recorded on Bruker Maxis Plus instrument. Infrared spectra were recorded on a Jasco FT-IR-4700 using a $\mathrm{KBr}$ transmission cell in $\mathrm{CH}_{2} \mathrm{Cl}_{2}$. Microanalyses were performed at the London Metropolitan University by Stephen Boyer or Elemental Microanalysis Ltd.

\subsection{Preparation of $\left[\operatorname{Ir}(\mathrm{PNP}-14)\left(\eta^{2}: \eta^{2}-\mathrm{COD}\right)\right]\left[\mathrm{BAr}^{\mathrm{F}}{ }_{4}\right](1)$}

A solution of $\left[\operatorname{Ir}(\mathrm{COD})_{2}\right]\left[\mathrm{BAr}_{4}^{\mathrm{F}}\right](29.3 \mathrm{mg}, 23.0 \mu \mathrm{mol})$ and PNP-14 $(11.0 \mathrm{mg}, 23.0 \mu \mathrm{mol})$ in DFB $(0.5 \mathrm{~mL})$ was mixed for $5 \mathrm{~min}$ at RT, the volatiles were removed in vacuo and the resulting orange oil washed with pentane $(2 \times 2 \mathrm{~mL})$. The analytically pure product was obtained as a yellow crystalline solid by slow diffusion of $\mathrm{SiMe}_{4}(\mathrm{ca} .10 \mathrm{~mL})$ into a DFB solution (0.5 mL) at $-30{ }^{\circ} \mathrm{C}$. Yield: $29.0 \mathrm{mg}(17.7 \mu \mathrm{mol}, 77 \%)$.

${ }^{1}$ H NMR (500 MHz, DFB): $\delta 8.11-8.16\left(\mathrm{~m}, 8 \mathrm{H}, \mathrm{Ar}^{\mathrm{F}}\right), 7.50(\mathrm{br}$, $\left.4 \mathrm{H}, \mathrm{Ar}^{\mathrm{F}}\right), 7.33\left(\mathrm{t},{ }^{3} J_{\mathrm{HH}}=7.7,1 \mathrm{H}, \mathrm{py}\right), 7.08\left(\mathrm{~d},{ }^{3} J_{\mathrm{HH}}=7.7,1 \mathrm{H}, \mathrm{py}\right)$, 7.03 (obscured, py), 4.25-4.34 (m, $1 \mathrm{H}, \operatorname{Ir}(\mathrm{CH}=\mathrm{CH})\{$ axial $\}$ ), 4.34-4.44 (m, 1H, $\operatorname{Ir}(\mathrm{CH}=\mathrm{CH})\{$ axial $\}), 3.72\left(\mathrm{~d},{ }^{2} J_{\mathrm{PH}}=6.6,2 \mathrm{H}\right.$, $\left.\mathrm{pyC}_{2}\right), 3.51\left(\mathrm{dd},{ }^{2} J_{\mathrm{HH}}=18.2,{ }^{2} J_{\mathrm{PH}}=6.0,1 \mathrm{H}, \mathrm{pyC}_{2}\right), 3.34(\mathrm{dd}$, $\left.{ }^{2} J_{\mathrm{HH}}=18.2,{ }^{2} J_{\mathrm{PH}}=9.7,1 \mathrm{H}, \mathrm{pyC}_{2}\right), 2.54-2.66\left(\mathrm{~m}, 2 \mathrm{H}, \mathrm{CH}_{2}\right)$, 2.15-2.45 $\left(\mathrm{m}, 6 \mathrm{H}, \mathrm{CH}_{2}+1 \times \operatorname{Ir}(\mathrm{CH}=\mathrm{CH})\{\right.$ equatorial $\left.\}[\delta 2.39]\right)$, 1.38-2.04 (m, 9H, $\mathrm{CH}_{2}+1 \times \operatorname{Ir}(\mathrm{CH}=\mathrm{CH})\{$ equatorial $\left.\}[\delta 1.83]\right)$, $1.38\left(\mathrm{~d},{ }^{3} J_{\mathrm{PH}}=12.7,9 \mathrm{H}, t \mathrm{Bu}\right), 0.94-1.32\left(\mathrm{~m}, 19 \mathrm{H}, \mathrm{CH}_{2}\right), 0.65(\mathrm{~d}$, $\left.{ }^{3} J_{\mathrm{PH}}=12.5,9 \mathrm{H}, t \mathrm{Bu}\right)$.

${ }^{13} \mathbf{C}\left\{{ }^{1} \mathbf{H}\right\}$ NMR $(126 \mathrm{MHz}, \mathrm{DFB}): \delta 163.7$ (dd, $\left.J_{\mathrm{PC}}=5,4, \mathrm{py}\right)$, $162.5\left(\mathrm{q},{ }^{1} J_{\mathrm{CB}}=50, \mathrm{Ar}^{\mathrm{F}}\right), 162.4$ (obscured, py), $138.2(\mathrm{~s}, \mathrm{py})$, $135.1\left(\mathrm{~s}, \mathrm{Ar}^{\mathrm{F}}\right), 129.7\left(\mathrm{qq},{ }^{2} J_{\mathrm{FC}}=32,{ }^{3} J_{\mathrm{CB}}=3, \mathrm{Ar}^{\mathrm{F}}\right), 124.9\left(\mathrm{q},{ }^{1} J_{\mathrm{FC}}=\right.$ $\left.272, \mathrm{Ar}^{\mathrm{F}}\right), 122.0\left(\mathrm{~d},{ }^{3} J_{\mathrm{PC}}=6\right.$, py), $120.7\left(\mathrm{~d},{ }^{3} J_{\mathrm{PC}}=8, \mathrm{py}\right), 117.6$ (sept, $\left.{ }^{3} J_{\mathrm{FC}}=4, \mathrm{Ar}^{\mathrm{F}}\right), 64.7(\mathrm{br}, \operatorname{Ir}(\mathrm{CH}=\mathrm{CH})\{$ axial $\}), 60.9\left(\mathrm{~d},{ }^{2} J_{\mathrm{PC}}=\right.$ $3, \operatorname{Ir}(\mathrm{CH}=\mathrm{CH})\{$ axial $\}), 60.2\left(\mathrm{dd},{ }^{2} J_{\mathrm{PC}}=27,4, \operatorname{Ir}(\mathrm{CH}=\mathrm{CH})\{\right.$ equatorial $\}), 50.1\left(\mathrm{dd},{ }^{2} J_{\mathrm{PC}}=29,{ }^{2} J_{\mathrm{PC}}=5, \operatorname{Ir}(\mathrm{CH}=\mathrm{CH})\{\right.$ equatorial $\left.\}\right)$, $45.6\left(\mathrm{dd},{ }^{1} J_{\mathrm{PC}}=27,{ }^{3} J_{\mathrm{PC}}=4, \mathrm{pyCH}_{2}\right) 42.3\left(\mathrm{~d},{ }^{1} J_{\mathrm{PC}}=22, \mathrm{pyCH}_{2}\right)$, $35.8\left(\mathrm{~d},{ }^{3} J_{\mathrm{PC}}=10, \mathrm{CH}_{2}\right), 35.5\left(\mathrm{br}, \mathrm{CH}_{2}\right), 35.2\left(\mathrm{dd},{ }^{1} J_{\mathrm{PC}}=19,{ }^{3} J_{\mathrm{PC}}\right.$ $=4, t \mathrm{Bu}\{\mathrm{C}\}), 34.1\left(\mathrm{~d},{ }^{1} J_{\mathrm{PC}}=7, \mathrm{PCH}_{2}\right), 33.4(\mathrm{br}, t \mathrm{Bu}\{\mathrm{C}\}), 31.1(\mathrm{~d}$, $\left.{ }^{3} J_{\mathrm{PC}}=10, \mathrm{CH}_{2}\right), 29.8\left(\mathrm{~d},{ }^{3} J_{\mathrm{PC}}=9, \mathrm{CH}_{2}\right), 29.7\left(\mathrm{~s}, \mathrm{CH}_{2}\right), 29.5(\mathrm{~s}$, $\left.\mathrm{CH}_{2}\right), 29.3\left(\mathrm{~d},{ }^{1} J_{\mathrm{PC}}=17, \mathrm{PCH}_{2}\right), 29.0\left(\mathrm{~s}, \mathrm{CH}_{2}\right), 28.8\left(\mathrm{~s}, \mathrm{CH}_{2}\right)$, $28.7\left(\mathrm{~s}, \mathrm{CH}_{2}\right), 28.6\left(\mathrm{br}, \mathrm{CH}_{2}\right), 28.3\left(\mathrm{~s}, \mathrm{CH}_{2}\right), 28.12\left(\mathrm{~s}, \mathrm{CH}_{2}\right), 28.05$ (s, $\left.\mathrm{CH}_{2}\right), 27.8\left(\mathrm{~d},{ }^{2} J_{\mathrm{PC}}=4, t \mathrm{Bu}\left\{\mathrm{CH}_{3}\right\}\right), 27.1\left(\mathrm{~d},{ }^{3} J_{\mathrm{PC}}=7, \mathrm{CH}_{2}\right)$, $27.0\left(\mathrm{~s}, \mathrm{CH}_{2}\right), 26.6\left(\mathrm{~s}, \mathrm{CH}_{2}\right), 26.4\left(\mathrm{~d},{ }^{2} J_{\mathrm{PC}}=5, t \mathrm{Bu}\left\{\mathrm{CH}_{3}\right\}\right)$.

${ }^{31} \mathbf{P}\left\{{ }^{1} \mathbf{H}\right\}$ NMR (162 MHz, DFB): $\delta 17.0(\mathrm{~s}, 1 \mathrm{P}), 13.4(\mathrm{~s}, 1 \mathrm{P})$. 
HR ESI-MS (positive ion $4 \mathrm{kV}$ ): $778.4221\left([M]^{+}\right.$, calcd 778.4218) $\mathrm{m} / \mathrm{z}$.

Anal. calcd for $\mathrm{C}_{69} \mathrm{H}_{77} \mathrm{BF}_{24} \mathrm{IrNP}_{2}\left(1641.32 \mathrm{~g} \mathrm{~mol}^{-1}\right)$ : C, 50.49; H, 4.73; N, 0.85. Found: C, 50.40; H, 4.64; N, 0.87 .

\subsection{NMR scale reaction of 1 with dihydrogen}

A solution of $1(12.2 \mathrm{mg}, 7.43 \mu \mathrm{mol})$ in DFB $(0.5 \mathrm{~mL})$ within a J. Young valve NMR tube was freeze-pump-thaw degassed and placed under an atmosphere of dihydrogen (1 atm). Analysis by NMR spectroscopy indicated quantitative formation of $\mathbf{4}$ with concomitant formation of COD within $5 \mathrm{~min}$ at RT.

\subsection{Preparation of $[\operatorname{Ir}(\mathrm{PNP}-14)(\mathrm{biph})]\left[\mathrm{BAr}_{4}^{\mathrm{F}}\right](2)$}

A suspension of PNP-14 (13.3 mg, $27.8 \mu \mathrm{mol})$ and [Ir(biph) $(\mathrm{COD}) \mathrm{Cl}]_{2}(13.7 \mathrm{mg}, 14.0 \mu \mathrm{mol})$ in fluorobenzene $(0.50 \mathrm{~mL})$ was stirred for 2 days at $50{ }^{\circ} \mathrm{C}$ to give a pale-yellow solution. $\mathrm{Na}$ $\left[\mathrm{BAr}_{4}^{\mathrm{F}}\right.$ ] $(24.7 \mathrm{mg}, 27.9 \mu \mathrm{mol})$ was added and the suspension stirred for a further $4 \mathrm{~h}$ at RT. The volatiles were removed in vacuo and the resulting purple oil was washed with pentane (2 $\times 1 \mathrm{~mL}$ ), dried in vacuo and then the product extracted into $\mathrm{CH}_{2} \mathrm{Cl}_{2}(2 \mathrm{~mL})$. The analytically pure product was obtained as a purple crystalline solid by recrystallisation from $\mathrm{CH}_{2} \mathrm{Cl}_{2}$ : hexane $(1: 20)$ at $-30{ }^{\circ} \mathrm{C}$. Yield: $36.4 \mathrm{mg}(21.6 \mu \mathrm{mol}$, $78 \%)$.

${ }^{1} \mathrm{H}$ NMR $\left(500 \mathrm{MHz}, \mathrm{CD}_{2} \mathrm{Cl}_{2}\right): \delta 8.00\left(\mathrm{t},{ }^{3} J_{\mathrm{HH}}=7.9, \mathrm{py}, 1 \mathrm{H}\right)$, 7.70-7.76 (m, 10H, py $\left.+\operatorname{Ar}^{\mathrm{F}}\right), 7.64\left(\mathrm{~d},{ }^{3} J_{\mathrm{HH}}=7.6,1 \mathrm{H}, \mathrm{biph}\right)$, $7.60\left(\mathrm{~d},{ }^{3} \mathrm{~J}_{\mathrm{HH}}=7.5,1 \mathrm{H}, \mathrm{biph}\right), 7.56\left(\mathrm{br}, 4 \mathrm{H}, \mathrm{Ar}^{\mathrm{F}}\right), 7.39\left(\mathrm{~d},{ }^{3} J_{\mathrm{HH}}=\right.$ 7.6, 1H, biph), $7.19\left(\mathrm{t},{ }^{3} J_{\mathrm{HH}}=7.3,1 \mathrm{H}\right.$, biph), $7.10\left(\mathrm{t},{ }^{3} J_{\mathrm{HH}}=7.5\right.$, $1 \mathrm{H}, \mathrm{biph}), 6.88\left(\mathrm{t},{ }^{3} \mathrm{~J}_{\mathrm{HH}}=7.4,1 \mathrm{H}, \mathrm{biph}\right), 6.33\left(\mathrm{t},{ }^{3} \mathrm{~J}_{\mathrm{HH}}=7.8,1 \mathrm{H}\right.$, biph), $5.35\left(\mathrm{~d},{ }^{3} J_{\mathrm{HH}}=8.2,1 \mathrm{H}\right.$, biph), $4.02\left(\mathrm{dd},{ }^{2} J_{\mathrm{HH}}=19.4,{ }^{2} J_{\mathrm{PH}}\right.$ $\left.=9.6,1 \mathrm{H}, \mathrm{pyCH}_{2}\right), 3.75-3.89\left(\mathrm{~m}, 2 \mathrm{H}, 2 \times \mathrm{pyCH}_{2}\right), 3.50\left(\mathrm{dd},{ }^{3} J_{\mathrm{HH}}\right.$ $\left.=17.0,{ }^{3} J_{\mathrm{HH}}=9.2,1 \mathrm{H}, \mathrm{pyCH}_{2}\right), 3.02-3.15\left(\mathrm{~m}, 1 \mathrm{H}, \mathrm{PCH}_{2}\right)$, 2.78-2.88 (m, 1H, $\left.\mathrm{PCH}_{2}\right), 1.88-1.98\left(\mathrm{~m}, 1 \mathrm{H}, \mathrm{CH}_{2}\right), 0.66-1.73$ $\left(\mathrm{m}, 23 \mathrm{H}, \mathrm{CH}_{2}\right), 1.16\left(\mathrm{~d},{ }^{3} J_{\mathrm{PH}}=14.0,9 \mathrm{H}, t \mathrm{Bu}\right), 0.49\left(\mathrm{~d},{ }^{3} J_{\mathrm{PH}}=\right.$ 16.1, 9H, $t \mathrm{Bu}), 0.22-0.37$ (m, 2H, $\left.\mathrm{CH}_{2}\right)$.

${ }^{13} \mathbf{C}\left\{{ }^{1} \mathbf{H}\right\}$ NMR $\left(126 \mathrm{MHz}, \mathrm{CD}_{2} \mathrm{Cl}_{2}\right): \delta 164.6$ (app t, $J_{\mathrm{PC}}=4$, py), 163.3 (br, py), 162.3 (q, $\left.{ }^{1} J_{\mathrm{CB}}=50, \mathrm{Ar}^{\mathrm{F}}\right), 150.6\left(\mathrm{~d},{ }^{3} J_{\mathrm{PC}}=2 \mathrm{biph}\right)$, 149.6 (s, biph), 145.3 (dd, $\left.{ }^{2} J_{\mathrm{PC}}=8,6, \operatorname{biph}\{\operatorname{IrC}\}\right), 139.9$ (s, py), $135.4\left(\mathrm{~s}, \mathrm{Ar}^{\mathrm{F}}\right), 135.2(\mathrm{~s}, \mathrm{biph}), 129.42\left(\mathrm{qq},{ }^{2} J_{\mathrm{FC}}=32,{ }^{3} J_{\mathrm{CB}}=3\right.$, $\mathrm{Ar}^{\mathrm{F}}$ ), 129.39 (s, biph), 126.3 (s, biph), 125.6 (s, biph), 125.3 (s, biph), 125.1 (q, $\left.{ }^{1} J_{\mathrm{FC}}=272, \mathrm{Ar}^{\mathrm{F}}\right), 123.5(\mathrm{~s}, \mathrm{biph}), 123.2\left(\mathrm{~d},{ }^{3} J_{\mathrm{PC}}=\right.$ 10, py), 123.1 (d, ${ }^{3} J_{\mathrm{PC}}=9$, py), 122.1 (s, biph), 121.3 (s, biph), $121.2\left(\operatorname{app~t},{ }^{2} J_{\mathrm{PC}}=6, \operatorname{biph}\{\operatorname{IrC}\}\right), 118.0\left(\mathrm{sept},{ }^{3} J_{\mathrm{FC}}=4, \mathrm{Ar}^{\mathrm{F}}\right), 40.9$ $\left(\mathrm{d},{ }^{1} J_{\mathrm{PC}}=29, \mathrm{pyCH}_{2}\right), 39.5\left(\mathrm{~d},{ }^{1} J_{\mathrm{PC}}=26, \mathrm{pyCH}_{2}\right), 35.0\left(\mathrm{~d},{ }^{1} J_{\mathrm{PC}}=\right.$ 23, $t \mathrm{Bu}\{\mathrm{C}\}$ ), 32.9 (d, ${ }^{2} J_{\mathrm{PC}}=14, \mathrm{CH}_{2}$ ), 32.8 (obscured, $t \mathrm{Bu}\{\mathrm{C}\}$ ), $30.4\left(\mathrm{~s}, \mathrm{CH}_{2}\right), 29.6\left(\mathrm{~s}, \mathrm{CH}_{2}\right), 29.5\left(\mathrm{~s}, \mathrm{CH}_{2}\right), 29.42\left(\mathrm{~s}, \mathrm{CH}_{2}\right), 29.35$

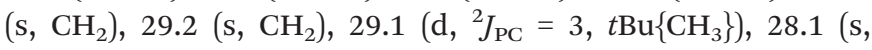
$\left.\mathrm{CH}_{2}\right), 27.9\left(\mathrm{~d},{ }^{1} J_{\mathrm{PC}}=28, \mathrm{PCH}_{2}\right), 27.3\left(\mathrm{~s}, \mathrm{CH}_{2}\right), 25.8\left(\mathrm{br}, \mathrm{CH}_{2}\right)$, $25.5\left(\mathrm{~s}, t \mathrm{Bu}\left\{\mathrm{CH}_{3}\right\}\right), 24.7\left(\mathrm{~s}, \mathrm{CH}_{2}\right), 24.1\left(\mathrm{~s}, \mathrm{CH}_{2}\right), 19.7\left(\mathrm{dd},{ }^{1} J_{\mathrm{PC}}=\right.$ $22,{ }^{3} \mathrm{JPC}_{\mathrm{PC}}=3, \mathrm{PCH}_{2}$ ).

${ }^{31} \mathbf{P}\left\{{ }^{1} \mathbf{H}\right\}$ NMR $\left(162 \mathrm{MHz}, \mathrm{CD}_{2} \mathrm{Cl}_{2}\right): \delta 38.7\left(\mathrm{~d},{ }^{2} J_{\mathrm{PP}}=307,1 \mathrm{P}\right)$, $20.9\left(\mathrm{~d},{ }^{2} J_{\mathrm{PP}}=307,1 \mathrm{P}\right)$.

HR ESI-MS (positive ion, $4 \mathrm{kV}): 822.3912\left([M]^{+}\right.$, calcd 822.3906) $\mathrm{m} / \mathrm{z}$.

Anal. calcd for $\mathrm{C}_{73} \mathrm{H}_{73} \mathrm{BF}_{24} \mathrm{IrNP}_{2}\left(1685.33 \mathrm{~g} \mathrm{~mol}^{-1}\right)$ : C, 52.03; H, 4.37; N, 0.83; found: C, 51.88; H, 4.28; N, 0.81 .

\subsection{NMR scale reactions of 2}

The following reactions were carried out starting with a solution of $2(16.9 \mathrm{mg}, 10.0 \mu \mathrm{mol})$ in $\mathrm{DFB}(0.5 \mathrm{~mL})$ within a J. Young valve NMR tube and analysed in situ by NMR spectroscopy.

4.5.1 Synthesis of $[\operatorname{Ir}(\mathbf{P N P}-14)(2-b i p h e n y l) H]\left[\operatorname{BAr}_{4}{ }_{4}\right]$ (3). The solution of 2 was freeze-pump-thaw degassed and placed under dihydrogen ( $1 \mathrm{~atm})$, resulting in quantitative formation of 3 within $5 \mathrm{~min}$ at RT. No free biphenyl was observed.

${ }^{1} \mathbf{H}$ NMR (400 MHz, DFB, $\mathrm{H}_{2}$, selected data): $\delta 7.61(\mathrm{t}$, ${ }^{3} J_{\mathrm{HH}}=7.8,1 \mathrm{H}$ py), 3.66-3.82 (m, 2H, $\left.2 \times \mathrm{pyCH}_{2}\right), 3.06$ (dd, $\left.{ }^{2} J_{\mathrm{HH}}=17.3,{ }^{2} J_{\mathrm{PH}}=6.4,1 \mathrm{H}, \mathrm{pyCH}_{2}\right), 0.79\left(\mathrm{~d},{ }^{3} J_{\mathrm{PH}}=13.4,9 \mathrm{H}\right.$, $t \mathrm{Bu}), 0.67\left(\mathrm{~d},{ }^{3} J_{\mathrm{PH}}=14.1,9 \mathrm{H}, t \mathrm{Bu}\right),-21.6\left(\mathrm{app} \mathrm{t},{ }^{2} J_{\mathrm{PH}}=15\right.$, $1 \mathrm{H}, \mathrm{IrH})$.

${ }^{31} \mathbf{P}\left\{\right.$ partial $\left.{ }^{1} \mathbf{H}\right\}$ NMR $\left(162 \mathrm{MHz}, \mathrm{DFB}, \mathrm{H}_{2}\right): \delta 40.6\left(\mathrm{dd},{ }^{2} J_{\mathrm{PP}}=\right.$ $\left.302,{ }^{2} J_{\mathrm{PH}}=14,1 \mathrm{P}\right), 36.5\left(\mathrm{dd},{ }^{2} J_{\mathrm{PP}}=302,{ }^{2} J_{\mathrm{PH}}=14,1 \mathrm{P}\right)$.

4.5.2 Synthesis of $\left[\operatorname{Ir}(\mathbf{P N P}-14) \mathrm{H}_{2}\left(\mathrm{H}_{2}\right)\right]\left[\mathrm{BAr}_{4}^{\mathrm{F}}\right]$ (4). The solution of 3 was heated at $85{ }^{\circ} \mathrm{C}$ for $6 \mathrm{~h}$, resulting quantitative formation 4 with concomitant formation of biphenyl $\left(\delta_{1_{\mathrm{H}}} 7.42\right.$, 7.25, 7.16).

${ }^{1}$ H NMR (500 MHz, DFB, $\left.\mathrm{H}_{2}\right): \delta 8.10-8.16\left(\mathrm{~m}, 8 \mathrm{H}, \mathrm{Ar}^{\mathrm{F}}\right), 7.49$ (br, $\left.4 \mathrm{H}, \mathrm{Ar}^{\mathrm{F}}\right), 7.47\left(\mathrm{t},{ }^{3} J_{\mathrm{HH}}=7.8,1 \mathrm{H}, \mathrm{py}\right), 7.19\left(\mathrm{~d},{ }^{3} J_{\mathrm{HH}}=7.8,2 \mathrm{H}\right.$, py), $3.96\left(\mathrm{dvt},{ }^{2} J_{\mathrm{HH}}=17.6, J_{\mathrm{PH}}=8,2 \mathrm{H}, \mathrm{pyCH}_{2}\right), 3.12\left(\mathrm{dvt},{ }^{2} J_{\mathrm{HH}}=\right.$ $\left.17.6, J_{\mathrm{PH}}=10,2 \mathrm{H}, \mathrm{pyC}_{2}\right), 2.11-2.23\left(\mathrm{~m}, 2 \overline{\mathrm{H}}, \mathrm{PCH}_{2}\right), 1.12-1.69$ $\left(\mathrm{m}, 26 \mathrm{H}, \mathrm{CH}_{2}\right), 0.91\left(\mathrm{vt}, J_{\mathrm{PH}}=16,18 \mathrm{H}, t \mathrm{Bu}\right),-9.27(\mathrm{br}, \mathrm{fwhm}=$ $\left.24 \mathrm{~Hz}, 4 \mathrm{H}, \mathrm{IrH}_{4}\right)$.

${ }^{13} \mathbf{C}\left\{{ }^{1} \mathbf{H}\right\}$ NMR (126 MHz, DFB, $\left.\mathrm{H}_{2}\right): \delta 162.3$ (q, ${ }^{1} J_{\mathrm{CB}}=50$, $\left.\mathrm{Ar}^{\mathrm{F}}\right), 162.4\left(\mathrm{vt}, J_{\mathrm{PC}}=6, \mathrm{py}\right), 138.9(\mathrm{~s}, \mathrm{py}), 135.1\left(\mathrm{~s}, \mathrm{Ar}^{\mathrm{F}}\right), 129.7$ $\left(\mathrm{qq},{ }^{2} J_{\mathrm{FC}}=32,{ }^{3} J_{\mathrm{CB}}=3, \mathrm{Ar}^{\mathrm{F}}\right), 124.9\left(\mathrm{q},{ }^{1} J_{\mathrm{FC}}=272, \mathrm{Ar}^{\mathrm{F}}\right), 120.4(\mathrm{vt}$, $J_{\mathrm{PC}}=10$, py), 117.6 (sept, $\left.{ }^{3} J_{\mathrm{FC}}=4, \mathrm{Ar}^{\mathrm{F}}\right), 44.4\left(\mathrm{vt}, J_{\mathrm{PC}}=28\right.$, $\left.\mathrm{pyCH}_{2}\right), 30.0\left(\mathrm{vt}, J_{\mathrm{PC}}=32, t \mathrm{Bu}\{\mathrm{C}\}\right), 29.0\left(\mathrm{~s}, \mathrm{CH}_{2}\right), 28.9\left(\mathrm{vt}, J_{\mathrm{PC}}=\right.$ 8, $\left.\mathrm{CH}_{2}\right), 28.3\left(\mathrm{~s}, \mathrm{CH}_{2}\right), 28.2\left(\mathrm{~s}, \mathrm{CH}_{2}\right), 27.5\left(\mathrm{~s}, \mathrm{CH}_{2}\right), 26.3(\mathrm{~s}$, $\mathrm{CH}_{2}$ ), 25.8 (vt, $J_{\mathrm{PC}}=32, \mathrm{PCH}_{2}$ ), 24.5 (vt, $J_{\mathrm{PC}}=6, t \mathrm{Bu}\left\{\mathrm{CH}_{3}\right\}$ ).

${ }^{31} \mathbf{P}\left\{{ }^{1} \mathbf{H}\right\}$ NMR (162 MHz, DFB, $\mathrm{H}_{2}$ )): $\delta 42.1$ (s, 2P).

${ }^{1}$ H NMR (600 MHz, DFB, Ar, $298 \mathrm{~K}$, selected data): $\delta-9.26$ (br, fwhm $=29 \mathrm{~Hz}, T_{1}=88.8 \pm 0.7 \mathrm{~ms}, 4 \mathrm{H}, \mathrm{IrH}$ ).

${ }^{1} \mathbf{H}$ NMR (600 MHz, DFB, Ar, $253 \mathrm{~K}$, selected data): $\delta-9.27$ (br, fwhm $=21 \mathrm{~Hz}, T_{1}=50 \pm 1,4 \mathrm{H}, \operatorname{IrH}$ ).

4.5.3 Synthesis of $\left[\operatorname{Ir}(\mathbf{P N P}-14) \mathrm{H}_{2}\left(\mathrm{C}_{2} \mathbf{H}_{4}\right)\right]\left[\mathrm{BAr}_{4}{ }_{4}\right]$ (5). The solution of 4 was freeze-pump-thaw degassed and placed under ethylene (1 atm), resulting in quantitative formation of 5 within 5 min at RT.

${ }^{1} \mathbf{H}$ NMR (500 MHz, DFB, $\mathrm{C}_{2} \mathrm{H}_{4}$, selected data): $\delta 7.43(\mathrm{t}$, $\left.{ }^{3} J_{\mathrm{HH}}=7.8,1 \mathrm{H}, \mathrm{py}\right), 3.71-3.84\left(\mathrm{~m}, 2 \mathrm{H}, 2 \times \mathrm{pyCH}_{2}\right), 3.18-3.37(\mathrm{~m}$, $\left.5 \mathrm{H}, 1 \times \mathrm{pyCH}_{2}+4 \times \mathrm{C}_{2} \mathrm{H}_{4}\right), 3.08\left(\mathrm{dd},{ }^{2} J_{\mathrm{HH}}=17.6,{ }^{2} J_{\mathrm{PH}}=10.4\right.$, $\left.1 \mathrm{H}, \mathrm{pyC}_{2}\right), 0.89\left(\mathrm{~d},{ }^{3} J_{\mathrm{PH}}=14.9,9 \mathrm{H}, t \mathrm{Bu}\right), 0.87\left(\mathrm{~d},{ }^{3} J_{\mathrm{PH}}=13.9\right.$, $9 \mathrm{H}, t \mathrm{Bu}),-7.89\left(\mathrm{dd},{ }^{2} J_{\mathrm{PH}}=17.6,{ }^{2} J_{\mathrm{PH}}=13.1,1 \mathrm{H}, \operatorname{IrH}\right),-17.80$ (app t, $J_{\mathrm{PH}}=11,1 \mathrm{H}, \mathrm{IrH}$ ).

${ }^{13} \mathbf{C}\left\{{ }^{1} \mathbf{H}\right\}$ NMR (126 MHz, DFB, $\mathrm{C}_{2} \mathrm{H}_{4}$, selected data): $\delta 48.7$ $\left(\mathrm{s}, \mathrm{C}_{2} \mathrm{H}_{4}\right)$.

${ }^{31} \mathbf{P}\left\{{ }^{1} \mathbf{H}\right\}$ NMR $\left(162 \mathrm{MHz}, \mathrm{DFB}, \mathrm{C}_{2} \mathrm{H}_{4}\right): \delta 33.4\left(\mathrm{~d},{ }^{2} J_{\mathrm{PP}}=314\right.$, 1P), $12.4\left(\mathrm{~d},{ }^{2} J_{\mathrm{PP}}=314,1 \mathrm{P}\right)$.

4.5.4 Synthesis of $\left[\operatorname{Ir}(\operatorname{PNP}-14)\left(\mathrm{C}_{2} \mathrm{H}_{4}\right)_{2}\right]\left[\mathrm{BAr}^{\mathrm{F}}{ }_{4}\right](6)$. The solution of 5 was heated at $85{ }^{\circ} \mathrm{C}$ for $16 \mathrm{~h}$, resulting in quantitative formation of $\mathbf{6}$, with concomitant formation of ethane $\left(\delta_{1_{\mathrm{H}}}\right.$ $\left.0.70, \delta_{1{ }^{3} \mathrm{C}} 6.1\right)$. 
${ }^{1} \mathrm{H}$ NMR (600 MHz, DFB, $\left.\mathrm{C}_{2} \mathrm{H}_{4}\right): \delta 8.11-8.15\left(\mathrm{~m}, 8 \mathrm{H}, \mathrm{Ar}^{\mathrm{F}}{ }_{4}\right)$, $7.50\left(\mathrm{br}, 4 \mathrm{H}, \mathrm{Ar}^{\mathrm{F}}{ }_{4}\right), 7.46\left(\mathrm{t},{ }^{3} J_{\mathrm{HH}}=7.8,1 \mathrm{H}, \mathrm{py}\right), 7.15\left(\mathrm{~d},{ }^{3} \mathrm{~J}_{\mathrm{HH}}=\right.$ $7.8,2 \mathrm{H}, \mathrm{py}), 3.63\left(\mathrm{dvt},{ }^{2} J_{\mathrm{HH}}=16.8, J_{\mathrm{PH}}=8,2 \mathrm{H}, \mathrm{pyCH}_{2}\right), 3.28$ $\left(\mathrm{dvt},{ }^{2} J_{\mathrm{HH}}=16.8, J_{\mathrm{PH}}=8,2 \mathrm{H}, \mathrm{pyC}_{2}\right), 3.23\left(\mathrm{br}, 2 \mathrm{H}, \mathrm{C}_{2} \overline{\mathrm{H}}_{4}\right), 2.80$ (br, 2H, $\mathrm{C}_{2} \mathrm{H}_{4}$ ), 2.49 (br, 2H, $\mathrm{C}_{2} \mathrm{H}_{4}$ ), 1.97 (br, 2H, $\mathrm{C}_{2} \mathrm{H}_{4}$ ), 1.03-1.48 (m, 28H, $\mathrm{CH}_{2}$ ), 0.79 (br, $\left.18 \mathrm{H}, t \mathrm{Bu}\right)$.

${ }^{13} \mathbf{C}\left\{{ }^{1} \mathbf{H}\right\}$ NMR (126 MHz, DFB, $\left.\mathrm{C}_{2} \mathrm{H}_{4}\right): \delta 164.1$ (d, ${ }^{3} J_{\mathrm{PC}}=3$, py), $162.6\left(\mathrm{q},{ }^{1} J_{\mathrm{CB}}=50, \mathrm{Ar}^{\mathrm{F}}\right), 139.1(\mathrm{~s}, \mathrm{py}), 135.1\left(\mathrm{~s}, \mathrm{Ar}^{\mathrm{F}}\right), 129.7$ $\left(\mathrm{qq},{ }^{2} J_{\mathrm{FC}}=32,{ }^{3} J_{\mathrm{CB}}=3, \mathrm{Ar}^{\mathrm{F}}\right), 124.9\left(\mathrm{q},{ }^{1} J_{\mathrm{FC}}=272, \mathrm{Ar}^{\mathrm{F}}\right), 119.8(\mathrm{vt}$, $J_{\mathrm{PC}}=8$, py), $117.6\left(\mathrm{sept},{ }^{3} J_{\mathrm{FC}}=4, \mathrm{Ar}^{\mathrm{F}}\right), 42.6\left(\mathrm{vt}, J_{\mathrm{PC}}=28, \mathrm{pyCH}_{2}\right)$, $33.5\left(\mathrm{vt}, J_{\mathrm{PC}}=26, t \mathrm{Bu}\{\mathrm{C}\}\right), 31.0\left(\mathrm{~s}, \mathrm{CH}_{2}\right), 29.1$ (vt, $\left.J_{\mathrm{PC}}=12, \mathrm{CH}_{2}\right)$, $27.8\left(\mathrm{~s}, \mathrm{CH}_{2}\right), 27.3\left(\mathrm{~s}, \mathrm{CH}_{2}\right), 27.2\left(\mathrm{~s}, \mathrm{CH}_{2}\right), 26.3\left(\mathrm{~s}, t \mathrm{Bu}\left\{\mathrm{CH}_{3}\right\}\right), 26.0$ $\left(\mathrm{s}, \mathrm{C}_{2} \mathrm{H}_{4}\right), 24.6\left(\mathrm{~s}, \mathrm{CH}_{2}\right), 18.0\left(\mathrm{~s}, \mathrm{C}_{2} \mathrm{H}_{4}\right), 14.3$ (vt, $\left.J_{\mathrm{PC}}=24, \mathrm{PCH}_{2}\right)$.

${ }^{31} \mathbf{P}\left\{{ }^{1} \mathbf{H}\right\}$ NMR (162 MHz, DFB, $\left.\mathrm{C}_{2} \mathrm{H}_{4}\right): \delta 9.0(\mathrm{~s}, 2 \mathrm{P})$.

4.5.5 Synthesis and isolation of $[\operatorname{Ir}(\mathrm{PNP}-14)(\mathrm{CO})]\left[\mathrm{BAr}^{\mathrm{F}}{ }_{4}\right](8)$. The solution of $\mathbf{6}$ was freeze-pump-thaw degassed and placed under carbon monoxide ( $1 \mathrm{~atm})$, resulting in an immediate colour change from colourless to bright yellow. The volatiles were removed in vacuo, and the resulting yellow oil washed with $\mathrm{SiMe}_{4}(2 \times 0.5 \mathrm{~mL})$ and thoroughly dried in vacuo to give the analytically pure product as a yellow foam. Yield: $13.9 \mathrm{mg}$ (8.90 $\mu \mathrm{mol}, 89 \%)$.

${ }^{1} \mathbf{H}$ NMR (500 MHz, $\left.\mathrm{CD}_{2} \mathrm{Cl}_{2}\right): \delta 7.87\left(\mathrm{t},{ }^{3} J_{\mathrm{HH}}=7.8,1 \mathrm{H}, \mathrm{py}\right)$, 7.70-7.76 (m, 8H, $\mathrm{Ar}^{\mathrm{F}}$ ), $7.56\left(\mathrm{br}, 4 \mathrm{H}, \mathrm{Ar}^{\mathrm{F}}\right), 7.51\left(\mathrm{~d},{ }^{3} J_{\mathrm{HH}}=7.9\right.$, $2 \mathrm{H}, \mathrm{py}), 3.94\left(\mathrm{dvt},{ }^{2} J_{\mathrm{HH}}=17.6, J_{\mathrm{PH}}=8,2 \mathrm{H}, \mathrm{pyCH}_{2}\right.$ ), 3.47 (dvt, $\left.{ }^{2} J_{\mathrm{HH}}=17.6, J_{\mathrm{PH}}=8,2 \mathrm{H}, \mathrm{pyCH}_{2}\right), 2.18-2.27\left(\mathrm{~m}, 4 \mathrm{H}, \mathrm{PCH}_{2}\right)$, 1.94-2.07 (m, 2H, $\left.\mathrm{CH}_{2}\right), 1.76-1.89\left(\mathrm{~m}, 2 \mathrm{H}, \mathrm{CH}_{2}\right), 1.64-1.74(\mathrm{~m}$, $\left.2 \mathrm{H}, \mathrm{CH}_{2}\right), 1.54-1.64\left(\mathrm{~m}, 2 \mathrm{H}, \mathrm{CH}_{2}\right), 1.23-1.48\left(\mathrm{~m}, 16 \mathrm{H}, \mathrm{CH}_{2}\right)$, $1.14\left(\mathrm{vt}, J_{\mathrm{PH}}=16,18 \mathrm{H}, t \mathrm{Bu}\right)$

${ }^{13} \mathbf{C}\left\{{ }^{1} \mathbf{H}\right\}$ NMR (126 MHz, $\mathrm{CD}_{2} \mathrm{Cl}_{2}$ ): $\delta 182.5$ (vt, $\left.{ }^{2} J_{\mathrm{PC}}=18, \mathrm{CO}\right)$, 165.4 (vt, $J_{\mathrm{PC}}=10$, py), $162.3\left(\mathrm{q},{ }^{1} J_{\mathrm{CB}}=50, \mathrm{Ar}^{\mathrm{F}}\right), 141.9$ (s, py), $135.4\left(\mathrm{~s}, \mathrm{Ar}^{\mathrm{F}}\right), 129.4\left(\mathrm{qq},{ }^{2} J_{\mathrm{FC}}=32,{ }^{3} J_{\mathrm{CB}}=3, \mathrm{Ar}^{\mathrm{F}}\right), 125.2\left(\mathrm{q},{ }^{1} J_{\mathrm{FC}}=\right.$ 272, $\mathrm{Ar}^{\mathrm{F}}$ ), 122.0 (vt, $\left.J_{\mathrm{PC}}=10, \mathrm{py}\right), 118.0\left(\mathrm{sept},{ }^{3} J_{\mathrm{FC}}=4, \mathrm{Ar}^{\mathrm{F}}\right), 39.4$ (vt, $J_{\mathrm{PC}}=24, \mathrm{pyCH}_{2}$ ), $34.7\left(\mathrm{vt}, J_{\mathrm{PC}}=30, t \mathrm{Bu}\{\mathrm{C}\}\right), 30.3\left(\mathrm{vt}, J_{\mathrm{PC}}=10\right.$ $\left.\mathrm{CH}_{2}\right), 29.3\left(\mathrm{~s}, \mathrm{CH}_{2}\right), 29.0\left(\mathrm{~s}, \mathrm{CH}_{2}\right), 28.9\left(\mathrm{~s}, \mathrm{CH}_{2}\right), 28.3\left(\mathrm{~s}, \mathrm{CH}_{2}\right)$, 27.5 (vt, $\left.J_{\mathrm{PC}}=6, t \mathrm{Bu}\left\{\mathrm{CH}_{3}\right\}\right), 26.1\left(\mathrm{~s}, \mathrm{CH}_{2}\right), 23.4$ (vt, $J_{\mathrm{PC}}=30$, $\mathrm{PCH}_{2}$ ).

${ }^{31} \mathbf{P}\left\{{ }^{1} \mathbf{H}\right\}$ NMR (162 MHz, $\left.\mathrm{CD}_{2} \mathrm{Cl}_{2}\right): \delta 64.6(\mathrm{~s}, 2 \mathrm{P})$.

${ }^{31} \mathbf{P}\left\{{ }^{1} \mathbf{H}\right\}$ NMR (162 MHz, DFB): $\delta 62.5$ (s, 2P).

IR $\left(\mathrm{CH}_{2} \mathrm{Cl}_{2}\right): \nu(\mathrm{CO}) 1984 \mathrm{~cm}^{-1}$.

HR ESI-MS (positive ion, $4 \mathrm{kV}): 698.3217\left([M]^{+}\right.$, calcd 698.3228) $\mathrm{m} / \mathrm{z}$.

Anal. calcd for $\mathrm{C}_{62} \mathrm{H}_{65} \mathrm{BF}_{24} \operatorname{IrNOP}_{2}\left(1561.14 \mathrm{~g} \mathrm{~mol}^{-1}\right)$ : C, 47.70; H, 4.20; N, 0.90; found: C, 47.89; H, 4.13; N, 0.97 .

\subsection{NMR scale reaction of $[\operatorname{Ir}(\mathrm{PNP}-t \mathrm{Bu})(\mathrm{biph})]\left[\mathrm{BAr}^{\mathrm{F}}{ }_{4}\right]$ (II) with dihydrogen}

A solution of II $(16.0 \mathrm{mg}, 9.98 \mu \mathrm{mol})$ in DFB $(0.5 \mathrm{~mL})$ within a J. Young valve NMR tube was freeze-pump-thaw degassed and placed under dihydrogen ( $1 \mathrm{~atm})$ and then heated at $80{ }^{\circ} \mathrm{C}$ for 2 days. Analysis by NMR spectroscopy indicated quantitative formation of $\left[\operatorname{Ir}(\mathrm{PNP}-t \mathrm{Bu}) \mathrm{H}_{2}\left(\mathrm{H}_{2}\right)\right]\left[\mathrm{BAr}^{\mathrm{F}}{ }_{4}\right]$. The spectroscopic data are consistent with the literature for the related $\mathrm{BF}_{4}{ }^{-}$salt. ${ }^{7}$

${ }^{1} \mathrm{H}$ NMR (400 MHz, $\mathrm{CD}_{2} \mathrm{Cl}_{2}$, selected data): $\delta$ 8.11-8.17 (m, $8 \mathrm{H}, \mathrm{Ar}^{\mathrm{F}}$ ), $7.50\left(\mathrm{~s}, 4 \mathrm{H}, \mathrm{Ar}^{\mathrm{F}}\right.$ ), 3.52 (vt, $\left.J_{\mathrm{PH}}=8,4 \mathrm{H}, \mathrm{pyCH}_{2}\right), 1.11$ $\left(\mathrm{vt}, J_{\mathrm{PH}}=14,36 \mathrm{H}, t \mathrm{Bu}\right),-9.48$ (br, $\left.4 \mathrm{H}, \mathrm{IrH}\right)$.
${ }^{31} \mathbf{P}\left\{{ }^{1} \mathbf{H}\right\}$ NMR (162 MHz, DFB): $\delta 64.6(\mathrm{~s}, 2 \mathrm{P})$.

\subsection{Preparation of $\left[\operatorname{Ir}\left(\mathbf{P N P}-14^{*}\right) \mathbf{H}\right]\left[\mathrm{BAr}^{\mathrm{F}}{ }_{4}\right](7)$}

A solution of 4 (13.6 $\mu \mathrm{mol}$, generated in situ as described above) in DFB $(0.5 \mathrm{~mL})$ within a J. Young valve NMR tube was treated with 3,3-dimethylbutene $(8.8 \mu \mathrm{L}, 71.4 \mu \mathrm{mol})$ and the solution heated at $100{ }^{\circ} \mathrm{C}$ for 5 days. Analysis by NMR spectroscopy indicated quantitative formation of the product. The volatiles were removed in vacuo and the resulting pink/red oil washed with $\mathrm{SiMe}_{4}(2 \times 0.5 \mathrm{~mL})$. The analytically pure product was obtained as pale red blocks by the slow diffusion of excess $\mathrm{SiMe}_{4}$ into a DFB solution at $-30{ }^{\circ} \mathrm{C}$. Yield: $10.2 \mathrm{mg}$ (6.66 $\mu \mathrm{mol}, 49 \%)$.

${ }^{1}$ H NMR (500 MHz, $\left.\mathrm{CD}_{2} \mathrm{Cl}_{2}\right): \delta 7.70-7.75\left(\mathrm{~m}, 8 \mathrm{H}, \mathrm{Ar}^{\mathrm{F}}\right), 7.65$ $\left(\mathrm{t},{ }^{3} J_{\mathrm{HH}}=7.8,1 \mathrm{H}, \mathrm{py}\right), 7.56\left(\mathrm{br}, 4 \mathrm{H}, \mathrm{Ar}^{\mathrm{F}}\right), 7.34\left(\mathrm{~d},{ }^{3} J_{\mathrm{HH}}=7.8\right.$, $1 \mathrm{H}$, py), 7.31 (d, ${ }^{3} J_{\mathrm{HH}}=7.8,1 \mathrm{H}$, py), 4.86 (app q, $J_{\mathrm{HH}}=9,1 \mathrm{H}$, $\mathrm{IrCH}), 4.47$ (app t, $\left.{ }^{3} \mathrm{JHH}_{\mathrm{HH}}=7,1 \mathrm{H}, \mathrm{IrCH}\right), 3.71-3.81(\mathrm{~m}, 2 \mathrm{H}, 2 \times$ $\left.\mathrm{pyCH}_{2}\right), 3.41\left(\mathrm{dd},{ }^{2} J_{\mathrm{HH}}=17.1,{ }^{2} J_{\mathrm{PH}}=9.3,1 \mathrm{H}, \mathrm{pyCH}_{2}\right), 3.26$ $\left(\mathrm{dd},{ }^{2} J_{\mathrm{HH}}=17.4,{ }^{2} J_{\mathrm{PH}}=9.2,1 \mathrm{H}, \mathrm{pyCH}_{2}\right), 2.35-2.52(\mathrm{~m}, 1 \mathrm{H}$, $\left.\mathrm{CH}_{2}\right)$, 2.15-2.29 (m, 1H, $\left.\mathrm{CH}_{2}\right), 1.98-2.11\left(\mathrm{~m}, 1 \mathrm{H}, \mathrm{CH}_{2}\right)$, 0.94-1.95 (m, 20H, IrCH $\left.[\delta 1.89]+\mathrm{CH}_{2}\right), 1.17\left(\mathrm{~d},{ }^{3} J_{\mathrm{PH}}=15.4\right.$, $9 \mathrm{H}, t \mathrm{Bu}), 1.01\left(\mathrm{~d},{ }^{3} J_{\mathrm{PH}}=13.5,9 \mathrm{H}, t \mathrm{Bu}\right),-8.49\left(\mathrm{dd},{ }^{2} J_{\mathrm{PH}}=19.6\right.$, 9.7, $1 \mathrm{H}, \mathrm{IrH})$.

${ }^{13} \mathbf{C}\left\{{ }^{1} \mathbf{H}\right\}$ NMR (126 MHz, $\mathrm{CD}_{2} \mathrm{Cl}_{2}$ ): $\delta 163.4$ (br, py), 162.3 (q, $\left.{ }^{1} J_{\mathrm{CB}}=50, \mathrm{Ar}^{\mathrm{F}}\right), 161.9(\mathrm{br}, \mathrm{py}), 138.5$ (s, py), $135.4\left(\mathrm{~s}, \mathrm{Ar}^{\mathrm{F}}\right), 129.4$ $\left(\mathrm{qq},{ }^{2} J_{\mathrm{FC}}=32,{ }^{3} J_{\mathrm{CB}}=3, \mathrm{Ar}^{\mathrm{F}}\right), 125.1\left(\mathrm{q},{ }^{1} J_{\mathrm{FC}}=272, \mathrm{Ar}^{\mathrm{F}}\right), 121.0(\mathrm{~d}$, ${ }^{3} J_{\mathrm{PC}}=9$, py), $120.8\left(\mathrm{~d},{ }^{3} J_{\mathrm{PC}}=9\right.$, py), $118.0\left(\mathrm{sept},{ }^{3} J_{\mathrm{FC}}=4, \mathrm{Ar}^{\mathrm{F}}\right)$, $81.9(\mathrm{~s}, \operatorname{IrCH}), 66.0\left(\mathrm{~d},{ }^{2} J_{\mathrm{PC}}=5, \operatorname{IrCH}\right), 41.9\left(\mathrm{~d},{ }^{1} J_{\mathrm{PC}}=30\right.$, pyㅡㄴ $\left.{ }_{2}\right), 39.2\left(\mathrm{~d},{ }^{1} J_{\mathrm{PC}}=29, \operatorname{pyCH}_{2}\right), 38.9(\mathrm{~s}, \operatorname{IrCH}), 35.9\left(\mathrm{~s}, \mathrm{CH}_{2}\right)$, $35.0\left(\mathrm{dd},{ }^{1} J_{\mathrm{PC}}=22,{ }^{3} J_{\mathrm{PC}}=5, t \mathrm{Bu}\{\mathrm{C}\}\right), 30.4\left(\mathrm{dd},{ }^{1} J_{\mathrm{PC}}=22,{ }^{3} J_{\mathrm{PC}}=\right.$ $5, t \mathrm{Bu}\{\mathrm{C}\}), 29.6\left(\mathrm{~s}, \mathrm{CH}_{2}\right), 27.8\left(\mathrm{~d},{ }^{2} J_{\mathrm{PC}}=14, \mathrm{CH}_{2}\right), 27.4\left(\mathrm{~s}, \mathrm{CH}_{2}\right)$, $27.0\left(\mathrm{~d},{ }^{2} J_{\mathrm{PC}}=3, t \mathrm{Bu}\left\{\mathrm{CH}_{3}\right\}\right), 25.7\left(\mathrm{~d},{ }^{2} J_{\mathrm{PC}}=4, t \mathrm{Bu}\left\{\mathrm{CH}_{3}\right\}\right), 24.8$ $\left(\mathrm{dd},{ }^{1} J_{\mathrm{PC}}=28,{ }^{3} J_{\mathrm{PC}}=1, \mathrm{PCH}_{2}\right), 24.4\left(\mathrm{~s}, \mathrm{CH}_{2}\right), 24.3\left(\mathrm{~d},{ }^{2} J_{\mathrm{PC}}=5\right.$, $\left.\mathrm{CH}_{2}\right), 22.9\left(\mathrm{~s}, \mathrm{CH}_{2}\right), 22.3\left(\mathrm{~s}, \mathrm{CH}_{2}\right), 21.6\left(\mathrm{~s}, \mathrm{CH}_{2}\right), 20.8\left(\mathrm{dd},{ }^{1} J_{\mathrm{PC}}=\right.$ $24,{ }^{3} \mathrm{JC}_{\mathrm{PC}}=4, \mathrm{PCH}_{2}$ ).

${ }^{31} \mathbf{P}\left\{{ }^{1} \mathbf{H}\right\}$ NMR $\left(162 \mathrm{MHz}, \mathrm{CD}_{2} \mathrm{Cl}_{2}\right): \delta 81.4\left(\mathrm{~d},{ }^{2} J_{\mathrm{PP}}=313,1 \mathrm{P}\right)$, $25.8\left(\mathrm{~d},{ }^{2} J_{\mathrm{PP}}=313,1 \mathrm{P}\right)$.

${ }^{31} \mathbf{P}\left\{{ }^{1} \mathbf{H}\right\}$ NMR (162 MHz, DFB): $\delta 80.9\left(\mathrm{~d},{ }^{2} J_{\mathrm{PP}}=313,1 \mathrm{P}\right), 25.5$ $\left(\mathrm{d},{ }^{2} J_{\mathrm{PP}}=313,1 \mathrm{P}\right)$.

HR ESI-MS (positive ion $4 \mathrm{kV})$ : $668.3128\left([M]^{+}\right.$, calcd 668.3122) $\mathrm{m} / \mathrm{z}$.

Anal. calcd for $\mathrm{C}_{62} \mathrm{H}_{67} \mathrm{BF}_{24} \mathrm{IrNP}_{2}\left(1531.12 \mathrm{~g} \mathrm{~mol}^{-1}\right)$ : C, 47.85; H, 4.15; N, 0.91. Found: C, 47.65; H, 4.03; N, 1.01.

\subsection{NMR scale reaction of 7 with dihydrogen}

A solution of $7(7.7 \mathrm{mg}, 5.03 \mu \mathrm{mol})$ in DFB $(0.5 \mathrm{~mL})$ within a J Young valve NMR tube was freeze-pump-thaw degassed, placed under dihydrogen ( $1 \mathrm{~atm}$ ) and heated at $80^{\circ} \mathrm{C}$ for $16 \mathrm{~h}$. Analysis by NMR spectroscopy indicated quantitative formation of 4 .

\subsection{Catalytic homocoupling of 3,3-dimethylbutyne promoted} by 1

A solution of $1(8.2 \mathrm{mg}, 5.0 \mu \mathrm{mol})$ in DFB $(400 \mu \mathrm{L})$ within a J. Young NMR tube was treated with a solution of 3,3-dimethylbutyne $(62 \mu \mathrm{L}, 503 \mu \mathrm{mol})$ and the resulting homocoupling 
reaction producing only $Z-t \mathrm{BuC} \equiv \mathrm{CCHCH} t \mathrm{Bu}$ followed at $\mathrm{RT}$ in situ using NMR spectroscopy. The solution was mixed constantly when not in the spectrometer. Analysis after 1 hour indicated 28 TONs, with complete conversion observed within $6 \mathrm{~h}$. At this point, 10 was observed as the major organometallic species (88\%), with 1 the minor organometallic species (10\%). Further 3,3-dimethylbutyne $(31 \mu \mathrm{L}, 252 \mu \mathrm{mol})$ was added, resulting in further homocoupling, totalling 65 TONs and complete conversion of $\mathbf{1}$ to $\mathbf{1 0}$ after $24 \mathrm{~h}$. Spectroscopic data for $Z$ - $t \mathrm{BuC} \equiv \mathrm{CCHCH} t \mathrm{Bu}$ is consistent with literature values. ${ }^{32}$

Data for $Z$ - $t \mathrm{BuC} \equiv \mathrm{CCHCH} t \mathrm{Bu}:{ }^{1} \mathbf{H}$ NMR $(400 \mathrm{MHz}, \mathrm{DFB}$, selected data): $\delta 5.53\left(\mathrm{~d},{ }^{3} J_{\mathrm{HH}}=11.9,1 \mathrm{H}, \mathrm{CH}=\mathrm{CH}\right), 5.25(\mathrm{~d}$, $\left.{ }^{3} J_{\mathrm{HH}}=11.9,1 \mathrm{H}, \mathrm{CH}=\mathrm{CH}\right), 1.12(\mathrm{~s}, 9 \mathrm{H}, t \mathrm{Bu}), 1.11(\mathrm{~s}, 9 \mathrm{H}, t \mathrm{Bu})$.

\subsection{Preparation of $\left[\operatorname{Ir}(\mathrm{PNP}-14)\left(\eta^{3}-E-\mathrm{C}(\mathrm{C} \equiv \mathrm{C} t \mathrm{Bu}) \mathrm{CH} t \mathrm{Bu}\right)\left(\eta^{1}-E-\right.\right.$ $\mathrm{CHCH} t \mathrm{Bu})]\left[\mathrm{BAr}_{4}^{\mathrm{F}}\right]$ (10)}

A solution of $1(14.0 \mathrm{mg}, 8.53 \mu \mathrm{mol})$ in $\mathrm{DFB}(0.5 \mathrm{~mL})$ within a J Young valve NMR tube was treated with 3,3-dimethylbutyne $(210 \mu \mathrm{L}, 1.71 \mathrm{mmol})$ and stirred for $6 \mathrm{~h}$ at RT. Analysis by NMR spectroscopy indicated quantitative formation of the product. The volatiles were removed in vacuo, the resulting yellow oil washed with $\mathrm{SiMe}_{4}(2 \times 0.5 \mathrm{~mL})$ and dried in vacuo to afford the analytically product as a yellow solid. Yield: $11.6 \mathrm{mg}$ (6.52 $\mu \mathrm{mol}, 76 \%)$. Crystals suitable X-ray crystallography were obtained by slow diffusion of excess $\mathrm{SiMe}_{4}$ into an $\mathrm{Et}_{2} \mathrm{O}$ solution. From the $\mathrm{SiMe}_{4}$ washings $Z$ - $t \mathrm{BuC} \equiv \mathrm{CCHCH} t \mathrm{Bu}$ was obtained as a colourless oil in low yield. Yield: $4.6 \mathrm{mg}$ (28.0 $\mu \mathrm{mol}, 2 \%)$.

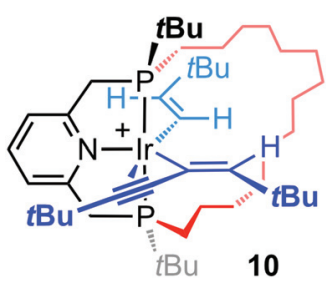

${ }^{1} \mathbf{H}$ NMR $\left(500 \mathrm{MHz}, \mathrm{CD}_{2} \mathrm{Cl}_{2}\right): \delta 7.83\left(\mathrm{t},{ }^{3} J_{\mathrm{HH}}=6.7,1 \mathrm{H}, \mathrm{py}\right)$, $7.81\left(\mathrm{dd},{ }^{3} J_{\mathrm{HH}}=15.0,{ }^{3} J_{\mathrm{PH}}=3,1 \mathrm{H}, \operatorname{IrCHCH} t \mathrm{Bu}\right), 7.70-7.75$ $\left(\mathrm{m}, 8 \mathrm{H}, \mathrm{Ar}^{\mathrm{F}}\right), 7.56\left(\mathrm{br}, 4 \mathrm{H}, \mathrm{Ar}^{\mathrm{F}}\right), 7.52\left(\mathrm{~d},{ }^{\overline{3}} \mathrm{~J}_{\mathrm{HH}}=7.9,1 \mathrm{H}, \mathrm{py}\right)$, $7.49\left(\mathrm{~d},{ }^{3} J_{\mathrm{HH}}=7.9,1 \mathrm{H}, \mathrm{py}\right), 5.68\left(\mathrm{t},{ }^{4} J_{\mathrm{PC}}=2,1 \mathrm{H}, \operatorname{IrCCH} t \mathrm{Bu}\right)$, $4.78\left(\mathrm{dt},{ }^{3} J_{\mathrm{HH}}=15.2,{ }^{4} J_{\mathrm{PH}}=2,1 \mathrm{H}, \operatorname{IrCHCH} t \mathrm{Bu}\right), 4.28(\mathrm{ddd}$, $\left.{ }^{2} J_{\mathrm{HH}}=16.5,{ }^{2} J_{\mathrm{PH}}=10.3,{ }^{4} J_{\mathrm{PH}}=3.0,1 \mathrm{H}, \mathrm{pyCH}_{2}\right), 3.69(\mathrm{ddd}$, $\left.{ }^{2} J_{\mathrm{HH}}=17.4,{ }^{2} J_{\mathrm{PH}}=10.1,{ }^{4} J_{\mathrm{PH}}=1.3,1 \mathrm{H}, \mathrm{pyCH}_{2}\right), 3.64\left(\mathrm{dd},{ }^{2} J_{\mathrm{HH}}\right.$ $\left.=17.4,{ }^{2} J_{\mathrm{PH}}=9.9,1 \mathrm{H}, \mathrm{pyCH}_{2}\right), 3.22\left(\mathrm{dd},{ }^{2} \mathrm{~J}_{\mathrm{HH}}=16.5,{ }^{2} J_{\mathrm{PH}}=\right.$ 7.9, $\left.1 \mathrm{H}, \mathrm{pyCH}_{2}\right), 2.28-2.43\left(\mathrm{~m}, 2 \mathrm{H}, \mathrm{CH}_{2}\right), 2.08-2.19(\mathrm{~m}, 1 \mathrm{H}$, $\left.\mathrm{CH}_{2}\right), 0.88-1.96\left(\mathrm{~m}, 25 \mathrm{H}, \mathrm{CH}_{2}\right), 1.24(\mathrm{~s}, 9 \mathrm{H}, \operatorname{IrCCH} t \mathrm{Bu}), 1.17$ $(\mathrm{s}, 9 \mathrm{H}, \mathrm{C} \equiv \underline{\mathrm{C} t \mathrm{Bu}}), 1.02\left(\mathrm{~d},{ }^{3} J_{\mathrm{PH}}=14,18 \mathrm{H}, 2 \times \mathrm{P} t \mathrm{Bu}\right), 1.00(\mathrm{~s}$, $9 \mathrm{H}, \mathrm{IrCHCH} t \mathrm{Bu})$.

${ }^{13} \mathbf{C}\left\{{ }^{1} \mathbf{H}\right\}$ NMR $\left(126 \mathrm{MHz}, \mathrm{CD}_{2} \mathrm{Cl}_{2}\right): \delta 164.2$ (app t, $\left.J_{\mathrm{PC}}=3, \mathrm{py}\right)$, 163.3 (app t, $J_{\mathrm{PC}}=3$, py), $162.3\left(\mathrm{q},{ }^{1} J_{\mathrm{CB}}=50, \mathrm{Ar}^{\mathrm{F}}\right), 143.5($ app t, $\left.{ }^{3} J_{\mathrm{PC}}=4, \operatorname{IrCHCH} t \mathrm{Bu}\right), 142.2(\mathrm{br}, \operatorname{IrCCH} t \mathrm{Bu}), 139.4$ (s, py), 135.4 $\left(\mathrm{s}, \mathrm{Ar}^{\mathrm{F}}\right), 129.4\left(\mathrm{qq},{ }^{2} J_{\mathrm{FC}}=32,{ }^{3} J_{\mathrm{CB}}=3, \mathrm{Ar}^{\mathrm{F}}\right), 125.1\left(\mathrm{q},{ }^{1} J_{\mathrm{FC}}=272\right.$, $\mathrm{Ar}^{\mathrm{F}}$ ), $121.7\left(\mathrm{~d},{ }^{3} J_{\mathrm{PC}}=8\right.$, py), 121.5 (d, ${ }^{3} J_{\mathrm{PC}}=8$, py), 118.0 (sept, $\left.{ }^{3} J_{\mathrm{FC}}=4, \mathrm{Ar}^{\mathrm{F}}\right), 116.9(\mathrm{~s}, \mathrm{C} \equiv \underline{\mathrm{C}} t \mathrm{Bu}), 105.3\left(\mathrm{dd},{ }^{2} J_{\mathrm{PC}}=8,{ }^{2} J_{\mathrm{PC}}=5\right.$, $\operatorname{IrCCH} t \mathrm{Bu}), 95.7$ (app t, $\left.{ }^{2} J_{\mathrm{PC}}=10, \operatorname{IrCHCH} t \mathrm{Bu}\right), 60.1(\mathrm{~s}$, $\underline{\mathrm{C}} \equiv \mathrm{C} t \mathrm{Bu}), 46.0\left(\mathrm{~d},{ }^{1} J_{\mathrm{PC}}=25, \mathrm{py}_{\underline{\mathrm{CH}}}\right), 40.8\left(\mathrm{~d},{ }^{1} J_{\mathrm{PC}}=30, \mathrm{pyCH}_{2}\right)$, $37.3(\mathrm{~s}, \mathrm{CHCH} t \mathrm{Bu}\{\mathrm{C}\}), 37.1(\mathrm{~s}, \mathrm{CCH} t \mathrm{Bu}\{\mathrm{C}\}), 36.6\left(\mathrm{dd},{ }^{1} J_{\mathrm{PC}}=21\right.$, $\left.{ }^{3} J_{\mathrm{PC}}=4, \mathrm{P} t \mathrm{Bu}\{\mathrm{C}\}\right), 34.6\left(\mathrm{dd},{ }^{1} J_{\mathrm{PC}}=21,{ }^{3} J_{\mathrm{PC}}=6, \mathrm{P} t \mathrm{Bu}\{\mathrm{C}\}\right), 33.3$ $\left(\mathrm{d},{ }^{2} J_{\mathrm{PC}}=15, \mathrm{CH}_{2}\right), 32.2\left(\mathrm{~s}, \mathrm{CH}_{2}\right), 31.8(\mathrm{~s}, \mathrm{C} \equiv \mathrm{C} t \mathrm{Bu}\{\mathrm{C}\}), 31.4(\mathrm{~s}$, $\mathrm{CH}_{2}$ ), $31.28\left(\mathrm{~s}, t \mathrm{Bu}\left\{\mathrm{CH}_{3}\right\}\right), 31.26\left(\mathrm{~s}, t \mathrm{Bu}\left\{\mathrm{CH}_{3}\right\}\right), 31.1\left(\mathrm{~s}, \mathrm{CH}_{2}\right)$, $30.5\left(\mathrm{~s}, \mathrm{CH}_{2}\right), 30.3\left(\mathrm{~s}, \mathrm{CH}_{2}\right), 30.2\left(\mathrm{~s}, \mathrm{CH}_{2}\right), 29.7(\mathrm{~s}, \mathrm{CHCH} t \mathrm{Bu}$ $\left.\left\{\mathrm{CH}_{3}\right\}\right), 28.8\left(\mathrm{br}, \mathrm{CH}_{2}\right), 28.20\left(\mathrm{~d},{ }^{2} J_{\mathrm{PC}}=4, \mathrm{CH}_{2}\right), 28.17\left(\mathrm{~s}, \mathrm{CH}_{2}\right)$, $27.1\left(\mathrm{~d},{ }^{2} J_{\mathrm{PC}}=3,2 \times \mathrm{P} t \mathrm{Bu}\left\{\mathrm{CH}_{3}\right\}\right), 26.6\left(\mathrm{~s}, \mathrm{CH}_{2}\right), 24.9\left(\mathrm{~s}, \mathrm{CH}_{2}\right)$, $21.9\left(\mathrm{dd},{ }^{1} J_{\mathrm{PC}}=30,{ }^{3} J_{\mathrm{PC}}=2, \mathrm{PCH}_{2}\right), 19.5\left(\mathrm{dd},{ }^{1} J_{\mathrm{PC}}=19,{ }^{3} J_{\mathrm{PC}}=3\right.$, $\mathrm{PCH}_{2}$ ).

${ }^{31} \mathbf{P}\left\{{ }^{1} \mathbf{H}\right\}$ NMR $\left(162 \mathrm{MHz}, \mathrm{CD}_{2} \mathrm{Cl}_{2}\right): \delta 25.5\left(\mathrm{~d},{ }^{2} J_{\mathrm{PP}}=364,1 \mathrm{P}\right)$, $16.8\left(\mathrm{~d},{ }^{2} J_{\mathrm{PP}}=364,1 \mathrm{P}\right)$.

${ }^{31} \mathbf{P}\left\{{ }^{1} \mathbf{H}\right\}$ NMR (121 MHz, DFB): $\delta 25.0\left(\mathrm{~d},{ }^{2} J_{\mathrm{PP}}=364,1 \mathrm{P}\right), 16.3$ $\left(\mathrm{d},{ }^{2} J_{\mathrm{PP}}=364,1 \mathrm{P}\right)$.

HR ESI-MS (positive ion, $4 \mathrm{kV}): 916.5623\left([M]^{+}\right.$, calcd 916.5628) $\mathrm{m} / \mathrm{z}$.

Anal. calcd for $\mathrm{C}_{79} \mathrm{H}_{95} \mathrm{BF}_{24} \mathrm{IrNP}_{2}\left(1779.57 \mathrm{~g} \mathrm{~mol}^{-1}\right)$ : C, 53.35; H, 5.38; N, 0.79. Found: C, 53.26; H, 5.09; N, 0.77.

\subsection{NMR scale reaction of 1 with $Z-t \mathrm{BuC} \equiv \mathrm{CCHCH} t \mathrm{Bu}$}

A solution of 1 (16.1, 9.8 $\mu \mathrm{mol})$ in DFB $(0.5 \mathrm{~mL})$ within a J. Young valve NMR tube was treated with $Z$ - $t \mathrm{BuC} \equiv \mathrm{CCHCH} t \mathrm{Bu}$ $\left(4.6 \mathrm{mg}, 28.0 \mu \mathrm{mol}\right.$ ) and then heated at $50^{\circ} \mathrm{C}$ for $1 \mathrm{~h}$. No reaction was apparent upon analysis by NMR spectroscopy.

\subsection{Crystallography}

Data were collected on a Rigaku Oxford Diffraction SuperNova AtlasS2 CCD diffractometer using graphite monochromated Mo $\mathrm{K} \alpha(\lambda=0.71073 \AA)$ or $\mathrm{CuK} \alpha(\lambda=1.54184 \AA)$ radiation and an Oxford Cryosystems N-HeliX low temperature device [150(2) $\mathrm{K}]$. Data were collected and reduced using CrysAlisPro and refined using SHELXL, ${ }^{39}$ through the Olex2 interface. ${ }^{40}$ Full details about the collection, solution, and refinement are documented in CIF format, which have been deposited with the Cambridge Crystallographic Data Centre under CCDC 2051203 (1), 2051204 (2), 2051205 (7), 2051206 (10), 2051207 $\left(\left[\mathrm{Rh}(\mathrm{PNP}-14)\left(\eta^{2}\right.\right.\right.$-norbornene $\left.\left.)\right]\left[\mathrm{BAr}_{4}^{\mathrm{F}}\right]\right) \cdot \dagger$

\section{Conflicts of interest}

There are no conflicts to declare.

\section{Acknowledgements}

We thank the European Research Council (ERC, grant agreement 637313) and Royal Society (UF100592, UF150675, A.B.C.) for financial support. High-resolution mass-spectrometry data were collected using instruments purchased through support from Advantage West Midlands and the European Regional Development Fund. Crystallographic data were collected using an instrument that received funding from the ERC under the European Union's Horizon 2020 research and innovation programme (grant agreement no. 637313). 


\section{References}

1 (a) Pincer Compounds: Chemistry and Applications, ed. D. Morales-Morales, Elsevier, 2018, vol. 1; (b) R. E. Andrew, L. González-Sebastián and A. B. Chaplin, Dalton Trans., 2016, 45, 1299-1305; (c) The Privileged Pincer-Metal Platform: Coordination Chemistry \& Applications, ed. G. van Koten and R. A. Gossage, Topics in Organometallic Chemistry, Springer, 2016, vol. 45; (d) J. R. Khusnutdinova and D. Milstein, Angew. Chem., Int. Ed., 2015, 54, 1223612273; (e) Pincer and Pincer-Type Complexes: Applications in Organic Synthesis and Catalysis, ed. K. J. Szabó and O. F. Wendt, Wiley-VCH, 2014; $(f)$ Organometallic Pincer Chemistry, ed. G. van Koten and D. Milstein, Topics in Organometallic Chemistry, Springer, 2013, vol. 40; (g) M. E. van der Boom and D. Milstein, Chem. Rev., 2003, 103, 1759-1792; $(h)$ M. Albrecht and G. van Koten, Angew. Chem., Int. Ed., 2001, 40, 3750-3781.

2 E. Peris and R. H. Crabtree, Chem. Soc. Rev., 2018, 47, 1959-1968.

3 (a) M. D. Walter, P. S. White, C. K. Schauer and M. Brookhart, J. Am. Chem. Soc., 2013, 135, 15933-15947; (b) W. H. Bernskoetter, C. K. Schauer, K. I. Goldberg and M. Brookhart, Science, 2009, 326, 553-556.

4 (a) A. Kumar, T. M. Bhatti and A. S. Goldman, Chem. Rev., 2017, 117, 12357-12384; (b) W. Yao, Y. Zhang, X. Jia and Z. Huang, Angew. Chem., Int. Ed., 2014, 53, 1390-1394; (c) J. Choi, A. H. R. MacArthur, M. Brookhart and A. S. Goldman, Chem. Rev., 2011, 111, 1761-1779; (d) A. S. Goldman, A. H. Roy, Z. Huang, R. Ahuja, W. Schinski and M. Brookhart, Science, 2006, 312, 257-261; (e) M. Gupta, C. Hagen, R. J. Flesher, W. C. Kaska and C. M. Jensen, Chem. Commun., 1996, 2083-2084.

5 (a) J. A. Labinger and J. E. Bercaw, Nature, 2002, 417, 507514; (b) A. E. Shilov and G. B. Shul'pin, Chem. Rev., 1997, 97, 2879-2932; (c) A. A. Bengali, R. H. Schultz, C. B. Moore and R. G. Bergman, J. Am. Chem. Soc., 1994, 116, 9585-9589; (d) J. K. Hoyano and W. A. G. Graham, J. Am. Chem. Soc., 1982, 104, 3723-3725; (e) A. H. Janowicz and R. G. Bergman, J. Am. Chem. Soc., 1982, 104, 352354.

6 T. M. Hood, B. Leforestier, M. R. Gyton and A. B. Chaplin, Inorg. Chem., 2019, 58, 7593-7601.

7 A. J. Holmes, P. J. Rayner, M. J. Cowley, G. G. R. Green, A. C. Whitwood and S. B. Duckett, Dalton Trans., 2015, 44, 1077-1083.

8 (a) M. Findlater, K. M. Schultz, W. H. Bernskoetter, A. Cartwright-Sykes, D. M. Heinekey and M. Brookhart, Inorg. Chem., 2012, 51, 4672-4467; (b) A. B. Chaplin and A. S. Weller, Organometallics, 2011, 30, 4466-4469.

9 W. H. Bernskoetter, S. K. Hanson, S. K. Buzak, Z. Davis, P. S. White, R. Swartz, K. I. Goldberg and M. Brookhart, J. Am. Chem. Soc., 2009, 131, 8603-8613.

10 D. Hermann, M. Gandelman, H. Rozenberg, L. J. W. Shimon and D. Milstein, Organometallics, 2002, 21, 812-818.
11 M. R. Gyton, B. Leforestier and A. B. Chaplin, Organometallics, 2018, 37, 3963-3971.

12 (a) C. M. Storey, M. R. Gyton, R. E. Andrew and A. B. Chaplin, Chem. - Eur. J., 2020, 26, 14715-17723; (b) C. M. Storey, A. Kalpokas, M. R. Gyton, T. Krämer and A. B. Chaplin, Chem. Sci., 2020, 11, 2051-2057; (c) C. M. Storey, M. R. Gyton, R. E. Andrew and A. B. Chaplin, Angew. Chem., Int. Ed., 2018, 57, 1200312006.

13 (a) R. E. Andrew, C. M. Storey and A. B. Chaplin, Dalton Trans., 2016, 45, 8937-8944; (b) R. E. Andrew, D. W. Ferdani, C. A. Ohlin and A. B. Chaplin, Organometallics, 2015, 34, 913-917; (c) R. E. Andrew and A. B. Chaplin, Inorg. Chem., 2015, 54, 312-322; (d) R. E. Andrew and A. B. Chaplin, Dalton Trans., 2014, 43, 1413-1423.

14 T. M. Hood, M. R. Gyton and A. B. Chaplin, Dalton Trans., 2020, 49, 2077-2086.

15 T. M. Hood and A. B. Chaplin, Dalton Trans., 2020, 49, 16649-16652.

16 (a) B. Leforestier, M. R. Gyton and A. B. Chaplin, Angew. Chem., Int. Ed., 2020, 59, 23500-23504; (b) B. Leforestier, M. R. Gyton and A. B. Chaplin, Dalton Trans., 2020, 49, 2087-2101.

17 G. E. M. Crisenza, N. G. McCreanor and J. F. Bower, J. Am. Chem. Soc., 2014, 136, 10258-10261.

18 Z. Lu, C.-H. Jun, S. R. de Gala, M. P. Sigalas, O. Eisenstein and R. H. Crabtree, Organometallics, 1995, 14, 1168-1175.

19 For structurally related examples see: (a) P. Hermosilla, P. López, P. Garcia-Orduna, F. J. Lahoz, V. Polo and M. A. Casado, Organometallics, 2018, 37, 2618-2629; (b) N. Grüger, H. Wadepohl and L. H. Gade, Eur. J. Inorg. Chem., 2013, 2013, 5358-5365; (c) P. Sánchez, M. Hernández-Juárez, E. Álvarez, M. Paneque, N. Rendón and A. Suárez, Dalton Trans., 2016, 45, 16997-17009; (d) J. J. Adams, N. Arulsamy and D. M. Roddick, Organometallics, 2011, 30, 697-711; (e) M. Yamashita, Y. Moroe, T. Yano and K. Nozaki, Inorg. Chim. Acta, 2011, 369, 15-18; $(f)$ R. Sablong and J. A. Osborn, Tetrahedron Lett., 1996, 37, 4937-4940.

20 Generation of $\left[\{\operatorname{Rh}(\mathrm{PNP}-14)\}_{2}\left(\mu_{2}-\eta^{2}: \eta^{2}-\mathrm{COD}\right)\right]^{2+}$ under equilibrium is also implied in this case, as this dication was the species ultimately obtained upon crystallisation (see ref. 15). Mononuclear formulation in solution is, however, substantiated by synthesis of $\left[\mathrm{Rh}(\mathrm{PNP}-14)\left(\eta^{2}-\right.\right.$ norbornene $)]\left[\mathrm{BAr}_{4}^{\mathrm{F}}\right]\left(\delta_{31 \mathrm{P}} 71.2,55.9 ;{ }^{2} J_{\mathrm{PP}}=244 \mathrm{~Hz}\right)$. Details, including solid-state structure, are provided in the ESI. $\dagger$

21 P. S. Pregosin, NMR in Organometallic Chemistry, Wiley-VCH, 2012, pp. 258-264.

22 (a) A. A. Danopoulos, D. Pugh and J. A. Wright, Angew. Chem., Int. Ed., 2008, 47, 9765-9767; (b) P. Paredes, J. Díez and M. P. Gamasa, Organometallics, 2008, 27, 2597-2607; (c) J. Díez, M. P. Gamasa, J. Gimeno and P. Paredes, Organometallics, 2005, 24, 1799-1802.

23 Mono-ethylene complexes have instead been reported, see: ref. $8 a$ and $25 f$. 
24 Reaction of 7 with dihydrogen ( $1 \mathrm{~atm}$ ) in DFB regenerates 4 in quantitative spectroscopic yield, within $16 \mathrm{~h}$ at $80^{\circ} \mathrm{C}$.

25 (a) S. Gu, R. J. Nielsen, K. H. Taylor, G. C. Fortman, J. Chen, D. A. Dickie, W. A. Goddard III and T. B. Gunnoe, Organometallics, 2020, 39, 1917-1933; (b) M. Rimoldi, A. Nakamura, N. A. Vermeulen, J. J. Henkelis, A. K. Blackburn, J. T. Hupp, J. F. Stoddart and O. K. Farha, Chem. Sci., 2016, 7, 4980-4984; (c) S. Kundu, J. Choi, D. Y. Wang, Y. Choliy, T. J. Emge, K. Krogh-Jespersen and A. S. Goldman, J. Am. Chem. Soc., 2013, 135, 5127-5143; (d) K. S. Lokare, R. J. Nielsen, M. Yousufuddin, W. A. Goddard III and R. A. Periana, Dalton Trans., 2011, 40, 9094; (e) A. V. Polukeev, S. A. Kuklin, P. V. Petrovskii, A. S. Peregudov, F. M. Dolgushin, M. G. Ezernitskaya and A. A. Koridze, Russ. Chem. Bull., 2010, 59, 745-749; (f) T. Yano, Y. Moroe, M. Yamashita and K. Nozaki, Chem. Lett., 2008, 37, 1300-1301; (g) F. Novak, B. Speiser, H. A. Y. Mohammad and H. A. Mayer, Electrochim. Acta, 2004, 49, 3841-3853; (h) H. A. Y. Mohammad, J. C. Grimm, K. Eichele, H.-G. Mack, B. Speiser, F. Novak, M. G. Quintanilla, W. C. Kaska and H. A. Mayer, Organometallics, 2002, 21, 5775-5784; (i) S. Nemeh, C. Jensen, E. Binamira-Soriaga and W. C. Kaska, Organometallics, 1983, 2, 1442-1447.

26 S. Khorasani, M. A. Fernandes and C. B. Perry, Cryst. Growth Des., 2012, 12, 5908-5916.

27 G. L. Parker, S. Lau, B. Leforestier and A. B. Chaplin, Eur. J. Inorg. Chem., 2019, 2019, 3791-3798.

28 (a) L. Maser, C. Schneider, L. Vondung, L. Alig and R. Langer, J. Am. Chem. Soc., 2019, 141, 7596-7604; (b) J. J. Davidson, J. C. DeMott, C. Douvris, C. M. Fafard, N. Bhuvanesh, C.-H. Chen, D. E. Herbert, C.-I. Lee, B. J. McCulloch, B. M. Foxman and O. V. Ozerov, Inorg. Chem., 2015, 54, 2916-2935.

29 S. M. Chapp and N. D. Schley, Inorg. Chem., 2020, 59, 71437149.

30 R. Ghosh, X. Zhang, P. Achord, T. J. Emge, K. KroghJespersen and A. S. Goldman, J. Am. Chem. Soc., 2007, 129, 853-866.

31 For examples of iridium catalysed terminal alkyne coupling reactions see: (a) M. Ez-Zoubir, F. Le Boucher d'Herouville, J. A. Brown, V. Ratovelomanana-Vidal and V. Michelet,
Chem. Commun., 2010, 46, 6332-6334; (b) K. Ogata and A. Toyota, J. Organomet. Chem., 2007, 692, 4139-4146; (c) T. Ohmura, S.-I. Yorozuya, Y. Yamamoto and N. Miyaura, Organometallics, 2000, 19, 365-367; (d) C.-H. Jun, Z. Lu and R. H. Crabtree, Tetrahedron Lett., 1992, 33, 7119-7120.

32 J. Alós, T. Bolaño, M. A. Esteruelas, M. Oliván, E. Oñate and M. Valencia, Inorg. Chem., 2013, 52, 6199-6213.

33 The bis(ethylene) complex 6 is also an effective precatalyst for this reaction (complete conversion within $6 \mathrm{~h}$ using $1 \mathrm{~mol} \%$ loading). Full details are provided in the ESI. $\dagger$

34 For a crystallographically characterised iridium $\eta^{1}$-enynyl complexes see: (a) J. S. Merola, T. L. Husebo and K. E. Matthews, Organometallics, 2012, 31, 3920-3929; (b) K. Ilg and H. Werner, Chem. - Eur. J., 2002, 8, 28122820; (c) T. X. Le and J. S. Merola, Organometallics, 1993, 12, 3798-3799.

35 For reviews see: (a) O. N. Temkin, Kinet. Catal., 2020, 60, 689-732; (b) Q. Liang, K. Hayashi and D. Song, ACS Catal., 2020, 10, 4895-4905; (c) B. M. Trost and J. T. Masters, Chem. Soc. Rev., 2016, 45, 2212-2238.

36 For recent or notable examples see: (a) N. Gorgas, B. Stöger, L. F. Veiros and K. Kirchner, ACS Catal., 2018, 8, 7973-7982; (b) O. Rivada-Wheelaghan, S. Chakraborty, L. J. W. Shimon, Y. Ben-David and D. Milstein, Angew. Chem., Int. Ed., 2016, 55, 6942-6945; (c) J. Alós, T. Bolaño, M. A. Esteruelas, M. Oliván, E. Oñate and M. Valencia, Inorg. Chem., 2014, 53, 1195-1209; (d) H. Katayama, H. Yari, M. Tanaka and F. Ozawa, Chem. Commun., 2005, 4336-4338; (e) C. Bianchini, M. Peruzzini, F. Zanobini, P. Frediani and A. Albinati, J. Am. Chem. Soc., 1991, 113, 5453-5454; see also ref. 32.

37 S. D. Pike, M. R. Crimmin and A. B. Chaplin, Chem. Commun., 2017, 53, 3615-3633.

38 (a) A. J. Martínez-Martínez and A. S. Weller, Dalton Trans., 2019, 48, 3551-3554; (b) W. E. Buschmann, J. S. Miller, K. Bowman-James and C. N. Miller, Inorg. Synth., 2002, 33, 83-91.

39 G. M. Sheldrick, Acta Crystallogr., Sect. C: Struct. Chem., 2015, 71, 3-8.

40 O. V. Dolomanov, L. J. Bourhis, R. J. Gildea, J. A. K. Howard and H. Puschmann, J. Appl. Crystallogr., 2009, 42, 339-341. 